Article

\title{
Synthesis, Antiproliferative Activity, and DNA Binding Studies of Nucleoamino Acid-Containing Pt(II) Complexes
}

\author{
Claudia Riccardi $^{1,+}+\mathbb{D}$, Domenica Capasso ${ }^{2,+}(\mathbb{D})$, Angela Coppola ${ }^{1}$, Chiara Platella ${ }^{1}$, \\ Daniela Montesarchio $^{1}\left(\mathbb{D}\right.$, Sonia Di Gaetano ${ }^{3}(\mathbb{D})$, Giovanni N. Roviello ${ }^{3}$ and \\ Domenica Musumeci $1,3, *$ (D) \\ 1 Department of Chemical Sciences, University of Napoli Federico II, 80126 Napoli, Italy; \\ claudia.riccardi@unina.it (C.R.); angelacoppola94@gmail.com (A.C.); chiara.platella@unina.it (C.P.); \\ montesar@unina.it (D.M.) \\ 2 CESTEV, University of Napoli Federico II, 80145 Napoli, Italy; domenica.capasso@unina.it \\ 3 CNR, Institute of Biostructure and Bioimaging, 80134 Napoli, Italy; digaetan@unina.it (S.D.G.); \\ giroviel@unina.it (G.N.R.) \\ * Correspondence: domenica.musumeci@unina.it; Tel.: +39-081-674143 \\ + These authors contributed equally to this work.
}

Received: 14 July 2020; Accepted: 28 September 2020; Published: 30 September 2020

\begin{abstract}
We here report our studies on the reaction with the platinum(II) ion of a nucleoamino acid constituted by the L-2,3-diaminopropanoic acid linked to the thymine nucleobase through a methylenecarbonyl linker. The obtained new platinum complexes, characterized by spectroscopic and mass spectrometric techniques, were envisaged to exploit synergistic effects due to the presence of both the platinum center and the nucleoamino acid moiety. The latter can be potentially useful to protect the complexes from early deactivation, as well as to facilitate their cell internalization. The biological activity of the complexes in terms of antiproliferative effects was evaluated in vitro on different cancer cell lines and healthy cells, showing the best results on human cervical adenocarcinoma (HeLa) cells along with good selectivity for cancer over normal cells. In contrast, the metal-free nucleoamino acid did not show any cytotoxicity on both normal and cancer cell lines. Finally, the ability of the novel Pt(II) complexes to bind various DNA model systems was investigated by circular dichroism (CD) spectroscopy and polyacrylamide gel electrophoresis analyses proving that the newly obtained compounds can potentially target DNA, similarly to other well-known anticancer Pt complexes, with a peculiar G-quadruplex vs. duplex selectivity.
\end{abstract}

Keywords: Pt(II) complexes; nucleoamino acid ligand; NMR spectroscopy; antiproliferative activity; DNA binding studies; CD spectroscopy

\section{Introduction}

Cisplatin (cis-diaminedichloro-platinum, CDDP) is one of the most active chemotherapeutic agents used for the treatment of a large variety of malignancies, especially testicular and ovarian carcinomas, even if its clinical utility is restricted by both toxicological and tumor resistance drawbacks [1,2]. CDDP activity and toxicity is mainly due to DNA binding [3,4], occurring via both inter- and intrastrand crosslinks, that suppresses DNA replication and also RNA transcription. Specifically, CDDP interacts with the DNA nucleobases forming stable platinum-nitrogen covalent bonds, which lead to irreversible adducts responsible for cisplatin antitumor activity [1,4].

The drawbacks and side effects of cisplatin treatment [1,2] have stimulated the design and synthesis of new anticancer Pt-based drugs with the aim of obtaining compounds more effective and 
less toxic than CDDP. Thus, in the last decades, a wide variety of Pt complexes have been tested for antiproliferative activity [5-7]. Some have also entered in clinical trials, but only a few have been approved for clinical use.

As ligands to be incorporated in Pt-based complexes, most studies focused on bioactive molecules, such as peptides [8], carbohydrates [7,9], fatty acids [10,11], amino acids (both proteinogenic or not) [8,12], nucleosides, nucleotides [13-15], and natural products [16], to obtain compounds with enhanced activity thanks to the synergistic effects of the Pt ion and the bioactive ligand. Since the aforementioned bioactive molecules are widespread in living organisms, when used as $\mathrm{Pt}(\mathrm{II})$ ligands, the metal center can be masked, retarding the complex deactivation or avoiding its recognition by a specific protein. Nucleosides or nucleobases represent an interesting class of molecules for drug conjugation, due to the presence in vivo of specific proteins which can favor their delivery and cellular internalization $[17,18]$. Thus, their conjugation to a reactive Pt center can produce molecules with remarkable biological properties. On the other side, amino acids may bind $\mathrm{Pt}(\mathrm{II})$ ions as bidentate chelates, providing a five-membered ring, including the platinum center, the $\alpha$-amino, and the $\alpha$-carboxylic acid functions $[8,19,20]$. Furthermore, polar and charged amino acids may also coordinate platinum through their side chains [19]. The nature and length of the side chains can also influence the solubility and membrane permeability of the resulting complexes and, consequently, the platinum concentration inside the cell [21]. It is interesting to consider the reaction between the metallic center and diamino acids, or, in general, amino acids containing in their side chains amino (lysine, arginine, and histidine) or amide (asparagine and glutamine) groups, that also exploit the side-chain function for the metal chelation $[19,22,23]$. Complexes with non-proteinogenic amino acids have also been realized, as in the case of the diamino acids ornithine, which binds platinum through the $\alpha-\mathrm{NH}_{2}$ and $\alpha-\mathrm{COOH}$ functions [8,22], and L-2,3-diaminopropanoic acid (DAP-OH), yielding Pt(II) complexes with a square planar structure in which both the $\alpha$-and $\beta$-amino groups of the diamino acid, along with the $\alpha$-amino and $\alpha$-carboxylic functions, can bind the Pt ion forming a 5-membered ring (Figure 1a) $[21,22,24]$.

a)

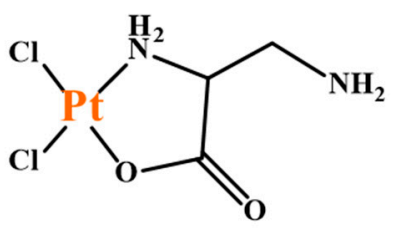<smiles>O=C(O)C1CN[PH](Cl)(Cl)[NH2+]1</smiles>

b)

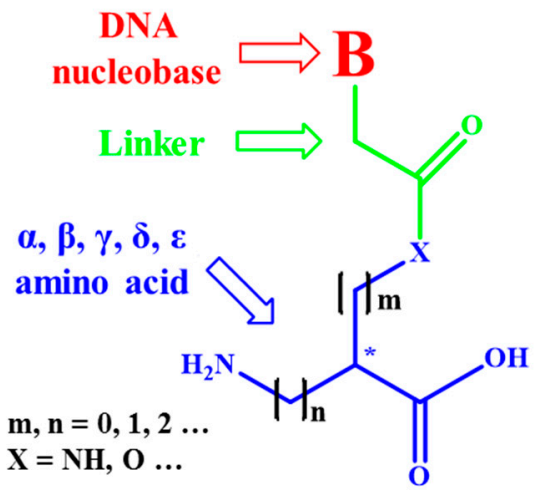

Figure 1. (a) Platinum complexes of L-2,3-diaminopropanoic acid (DAP-OH); (b) general structure of a nucleoamino acid.

Considering the capability of the platinum ion to bind both nucleobases and amino acids, our novel design consisted of $\mathrm{Pt}(\mathrm{II})$ complexes, incorporating as ligands nucleoamino acids, constituted by nucleobases linked to an amino acid through a suitable linker (Figure 1b), and thus, intrinsically containing various potential platinum binding sites. To the best of our knowledge, this is the first report on Pt complexes incorporating this kind of ligand. Nucleoamino acids have been widely explored in the literature, mainly as building blocks for the assembly of nucleopeptides, compounds potentially able to bind complementary nucleic acids in antisense/antigene strategies, or to give ordered self-assembly, a useful property in the context of the development of new nanomaterials [25-31].

Recently, a 9-fluorenylmethoxycarbonyl (Fmoc)-protected nucleoamino acid, obtained connecting the Fmoc-diaminopropanoic acid (Fmoc-DAP-OH) to the thymine acetic acid, was synthesized in our 
group and then used to obtain, via solid-phase peptide synthesis, a homothymine nucleopeptide for potential biomedical applications [30].

Here we used the deprotected $\mathrm{DAP}(\mathrm{T})-\mathrm{OH}$ nucleoamino acid for platinum complexation to obtain new Pt complexes in which synergistic anticancer effects were envisaged for the presence of both the nucleobase and the platinum center. The selected nucleoamino acid contained several donor groups for platinum (i.e., the nitrogen atoms of the $\alpha$-amino group, the nucleobase, or the amide in the methylenecarbonyl linker, and the oxygens of the carboxylic function of the nucleoamino acid) and could potentially form a large variety of Pt complexes. The compounds obtained from the platination reaction of $\mathrm{DAP}(\mathrm{T})-\mathrm{OH}$ were purified and characterized by nuclear magnetic resonance (NMR), mass spectrometry, and ultraviolet-visible (UV-vis) techniques. Then, the antiproliferative activity of the new $\mathrm{Pt}(\mathrm{II})$ complexes was evaluated in preliminary tests on different cancer cell lines and normal human cells, using the starting nucleoamino acid as a reference compound. Finally, in analogy to other metal complexes, the ability of the new $\mathrm{Pt}(\mathrm{II})$ complexes to bind DNA was also explored using circular dichroism (CD) and polyacrylamide gel electrophoresis analyses on different DNA model systems, both in random coil and in structured forms.

\section{Results and Discussion}

\subsection{Preparation of the Nucleoamino Acid Ligand}

The Fmoc-protected nucleoamino acid 3, based on L-2,3-diaminopropanoic acid and carrying the nucleobase thymine attached through a methylenecarbonyl linker to its $\beta$-amino group, was obtained as previously reported [30]. In brief, commercially available Fmoc-L-DAP(Boc)-OH (1, Scheme 1) was first treated with a trifluoroacetic acid (TFA) $/ \mathrm{CH}_{2} \mathrm{Cl}_{2}(1: 1, v / v)$ solution for the selective removal of the tert-butoxycarbonyl (Boc) protecting group from the $\beta$-amino function (almost quantitative yield). Then, the desired product 2 was coupled with thymine acetic acid using 1-[bis(dimethylamino)methylene]-1H-1,2,3-triazolo[4,5-b]pyridinium 3-oxid hexafluorophosphate/ $\mathrm{N}, \mathrm{N}$-diisopropylethylamine (HATU/DIEA) as the coupling agent, obtaining compound 3 in $80 \%$ overall yield. Fmoc removal from the DAP-moiety in 3 was quantitatively achieved upon treatment with piperidine. The final deprotected nucleoamino acid 4 was purified by high-performance liquid-chromatography (HPLC) and characterized by mass spectrometry (MS), i.e., matrix-assisted laser desorption ionization-time of flight (MALDI-TOF) and liquid chromatography-electrospray ionization (LC-ESI) MS (Figure S1), and NMR spectroscopy (Figures S2 and S3), which in all cases confirmed the identity and purity of the target compound.

\subsection{Platination of the DAP(T)-Based Nucleoamino Acid}

Analogously to previous works [5,12], the platination reaction was carried out mixing DAP(T)-OH (4, Scheme 1), as a Pt chelator, and $\mathrm{K}_{2} \mathrm{PtCl}_{4}$ in $\mathrm{CH}_{3} \mathrm{OH}: \mathrm{H}_{2} \mathrm{O}(9: 1, v / v)$ under stirring at room temperature in the dark. Subsequently, the solvent was removed under vacuum at low temperature, and the dried crude was sequentially treated with various organic solvents (see Materials and Methods) to dissolve the yellow solid. In detail, a solid-liquid extraction, followed by washings and centrifugations, using not significantly coordinating solvents with increasing polarity $\left(\mathrm{CH}_{2} \mathrm{Cl}_{2}, \mathrm{CHCl}_{3}, \mathrm{CH}_{3} \mathrm{COCH}_{3}, \mathrm{CH}_{3} \mathrm{OH}\right.$, $\left.\mathrm{H}_{2} \mathrm{O}\right)$, was performed. Neither the apolar solvents $\left(\mathrm{CH}_{2} \mathrm{Cl}_{2}, \mathrm{CHCl}_{3}\right)$ nor acetone were able to dissolve the solid allowing the recovery of the Pt complexes. In contrast, methanol was able to solubilize and recover a yellow product and, subsequently, $\mathrm{H}_{2} \mathrm{O}$ dissolved the second and last complex (see Materials and Methods). 


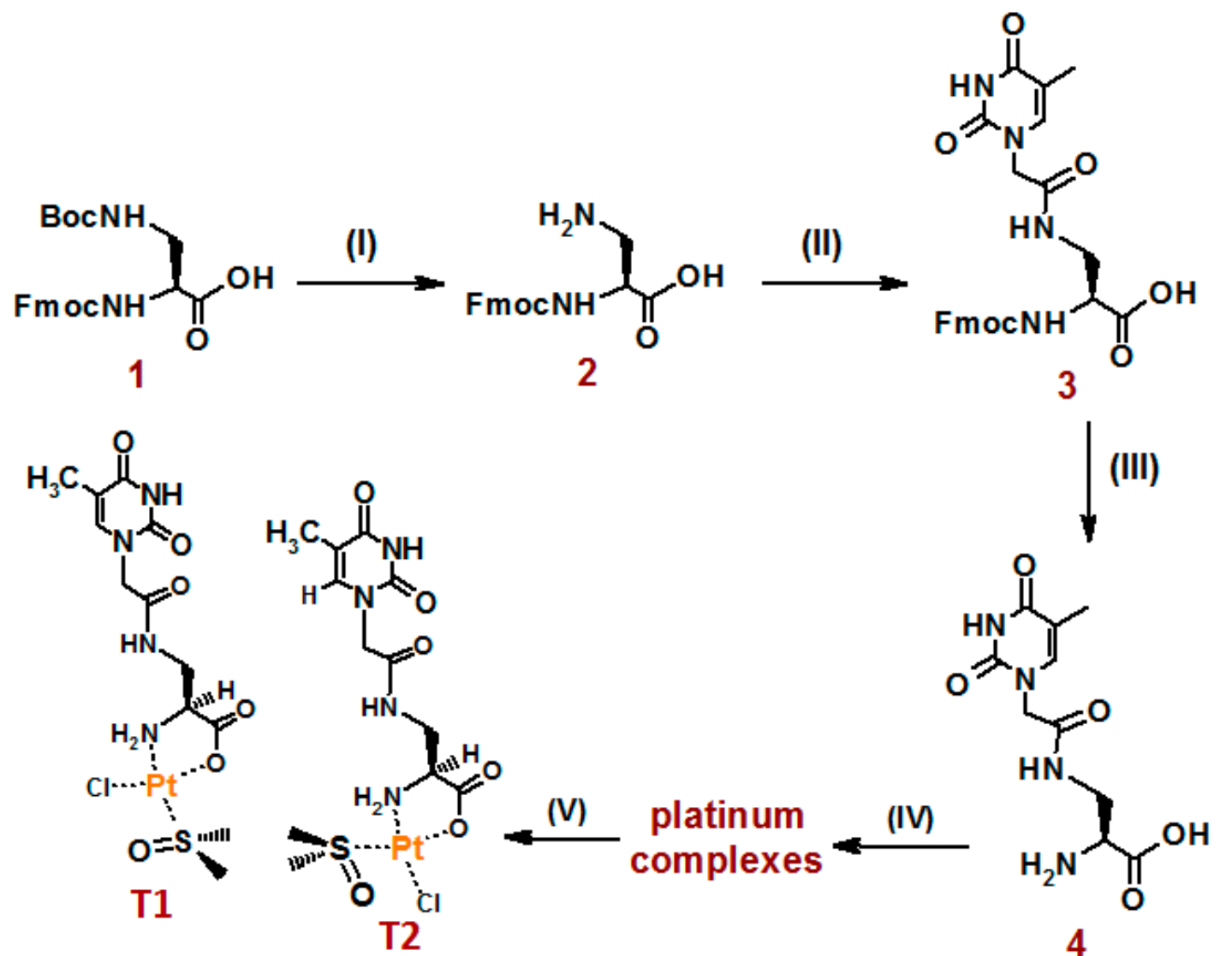

Scheme 1. Synthetic procedure for the preparation of the nucleoamino acid $\mathrm{DAP}(\mathrm{T})-\mathrm{OH}(4)$ and its platinum complexes. Reagents and conditions: (I) trifluoroacetic acid (TFA)/ $\mathrm{CH}_{2} \mathrm{Cl}_{2}(1: 1, v / v), 45^{\circ} \mathrm{C}$, $1.5 \mathrm{~h}$ (98\% yield); (II) thymine acetic acid, 1-[bis(dimethylamino)methylene]-1H-1,2,3-triazolo[4,5b]pyridinium 3-oxid hexafluorophosphate/N,N-diisopropylethylamine (HATU/DIEA) in N,Ndimethylformamide (DMF), $2 \mathrm{~h}$, room temperature (r.t.) (80\%); (III) piperidine (8 equiv.) in $\mathrm{DMF} / \mathrm{CH}_{3} \mathrm{OH}$ (9:1, v/v), r.t., $10 \mathrm{~min}(98 \%)$; (IV) $\mathrm{K}_{2} \mathrm{PtCl}_{4}$ in $\mathrm{CH}_{3} \mathrm{OH} / \mathrm{H}_{2} \mathrm{O}(9: 1, v / v), 6$ h, r.t., in the dark; (V) dimethyl sulfoxide (DMSO) dissolution of the platinum complexes obtained under conditions IV to favour DMSO-exchange reaction.

The two obtained products were subjected to LC-ESI-MS analysis, showing a single chromatographic peak in the total ion current (TIC) profile of the injection performed immediately after their dissolution $(t=0$, Figure $S 4 a$, left) with a complex mass spectrum denoting fragmentation during the ionization process (Figure S4a, right). Both the complexes showed almost the same peaks in the mass spectrum, evidencing that they followed the same fragmentation pattern and could probably be isomers (as an example, in Figure S4, we reported the LC-ESI-MS analysis of the methanol-recovered complex). From the analysis of the mass peaks of the complexes (Figure S4a, right), we could hypothesize that they both contained in their structures a DAP(T)-OH unit, platinum(II) and chloride ions, and a water molecule. The injection performed $10 \mathrm{~min}$ after the dissolution of both the compounds showed at least three peaks in the TIC profiles, each associated with a mass spectrum very difficult to interpret, evidencing that the Pt complexes are very unstable in aqueous solutions (Figure S4b) and, thus, difficult to handle for both their characterization and subsequent in vitro assays.

Then, since the most commonly used NMR organic solvents $\left(\mathrm{CDCl}_{3}, \mathrm{CD}_{3} \mathrm{OD}, \mathrm{CD}_{3} \mathrm{COCD}_{3}\right)$ were not able to solubilize the two products at the minimum concentration required for a complete NMR characterization, we decided to dissolve the complexes in a highly solubilizing solvent, such as $\mathrm{N}, \mathrm{N}$-dimethylformamide (DMF) or dimethyl sulfoxide (DMSO). Even if these solvents are well known to trigger exchange reactions with various $\mathrm{Pt}(\mathrm{II})$ ligands (see [5,15] for DMSO and [13] for DMF), in many cases, DMSO moieties were intentionally inserted in various bioactive platinum complexes to 
increase their activity and stability $[5,15]$. The compounds obtained after DMSO treatment (Scheme 1$)$ were named T1 and T2. They were derived, respectively, from the Pt complexes originally recovered with $\mathrm{CH}_{3} \mathrm{OH}$ and $\mathrm{H}_{2} \mathrm{O}$.

As expected, in the ESI mass spectra (positive ion-mode) of the DMSO-solubilized complexes, we effectively verified the occurrence of the exchange reaction realized by the solvent. Indeed, for both complexes, the found mass peaks were attributed to molecules containing a DAP(T)-OH unit, a platinum(II) ion, a chloride ion, and a DMSO molecule ( $\mathrm{m} / \mathrm{z}$ ca. 579, Figure S5a), indicating that the two complexes were either constitutional or geometrical isomers. In the recorded mass spectra, T1- and T2-adducts with $\mathrm{Na}^{+}$and $\mathrm{K}^{+}$ions were also found, respectively, at ca. 601 and $617 \mathrm{~m} / \mathrm{z}$ (Figure S5a).

The peak isotopic distribution for each species found in the mass spectra of the two isomers was almost superimposable to the theoretical one calculated with the Isotope Distribution Calculator program (http://www.sisweb.com/mstools/isotope.htm). As an example, we reported the comparison between the theoretical and experimental peak at ca. $579 \mathrm{~m} / \mathrm{z}$ of T1 (Figure S5b).

To verify how the nucleoamino acid ligand coordinated the platinum(II) ion in these isomers, mono- and bi-dimensional NMR experiments were carried out, recording all the spectra in DMSO- $\mathrm{d}_{6}$ (Figures S6-S8). The ${ }^{1} \mathrm{H}$ and ${ }^{13} \mathrm{C}-\mathrm{NMR}$ spectra of $\mathrm{DAP}(\mathrm{T})-\mathrm{OH}$ were used as references to evaluate the shifts of the corresponding signals in the complexes, thus obtaining information on the atoms directly involved in the coordination or influenced in their spectral properties by the proximity to the metal center. In Table 1 , the ${ }^{1} \mathrm{H}$ and ${ }^{13} \mathrm{C}$ NMR chemical shift values for $\mathbf{T} 1$ and $\mathbf{T} 2$ were reported in comparison to the starting ligand. Assignments were based on correlation spectroscopy (COSY), heteronuclear single quantum correlation (HSQC), and heteronuclear multiple-bond correlation (HMBC) experiments (Tables S1-S3).

Table 1. Nuclear magnetic resonance (NMR)-chemical shift assignments for T1 and T2 metal complexes compared to those of the starting nucleoamino acid $\mathrm{DAP}(\mathrm{T})-\mathrm{OH}$ (spectra recorded in dimethyl sulfoxide- $\mathrm{d}_{6}\left(\right.$ DMSO- $\left.\mathrm{d}_{6}\right)$. Chemical shift values in blue for $\mathbf{T} 1$ and $\mathbf{T} 2$ indicate signals very similar to those of the starting ligand, whereas those in red are the most diverging ones; green-colored chemical shift values evidence proton and carbon signals of T1 and T2 not present in the starting nucleoamino acid.

\begin{tabular}{|c|c|c|c|c|c|c|c|}
\hline \multicolumn{4}{|c|}{${ }^{1} \mathrm{H}-\mathrm{NMR}$} & \multicolumn{4}{|c|}{${ }^{13} \mathrm{C}-\mathrm{NMR}$} \\
\hline ppm & $\mathrm{DAP}(\mathrm{T})-\mathrm{OH}$ & T1 & T2 & ppm & DAP(T)-OH & T1 & T2 \\
\hline $\mathrm{CH}_{3}-5(\mathrm{~T})$ & 1.75 & 1.75 & 1.75 & $\mathrm{CH}_{3}-5(\mathrm{~T})$ & 11.87 & $11.93 / 11.91$ & 11.94 \\
\hline H-3 (T) & 11.25 & $11.29 / 11.28$ & 11.30 & C-2 (T) & 151.05 & 151.05 & 151.07 \\
\hline H-6 (T) & 7.41 & $7.44 / 7.43$ & 7.43 & $\mathrm{C}-4(\mathrm{~T})$ & 164.36 & $164.44 / 164.42$ & 164.47 \\
\hline A & 4.31 & 4.35 & 4.34 & C-5 (T) & 108.01 & $108.10 / 107.98$ & 108.16 \\
\hline $\mathrm{C}$ & 8.35 & $8.58 / 8.48$ & 8.43 & C-6 (T) & 142.31 & 142.24 & 142.23 \\
\hline $\mathrm{D}_{1}$ & 3.53 & $3.64 / 3.56$ & 3.55 & A & 49.16 & 49.22 & 49.27 \\
\hline $\mathrm{D}_{2}$ & 3.33 & $3.49 / 3.28$ & 3.29 & B & 167.77 & $168.86 / 168.31$ & 168.44 \\
\hline $\mathrm{E}$ & 3.27 & $3.90 / 3.52$ & 3.51 & D & 39.62 & $41.66 / 38.58$ & 41.69 \\
\hline $\mathrm{G}_{1}$ & - & 6.29 & 6.25 & E & 54.04 & $56.78 / 52.40$ & 56.90 \\
\hline $\mathrm{G}_{2}$ & - & 5.68 & 5.63 & $\mathbf{F}$ & 168.82 & 181.33 & 181.38 \\
\hline $\mathrm{CH}_{3}$ (DMSO-Pt) & & 3.16 & 3.16 & $\mathrm{CH}_{3}$ (DMSO-Pt) & & 49.02 & 48.61 \\
\hline
\end{tabular}

In particular, in the ${ }^{1} \mathrm{H}$ NMR spectra of $\mathbf{T} 1$ and $\mathbf{T} 2$ complexes, two signals, i.e., broad multiplets at 5.68 and 6.29 ppm (for T1, Figure S6, up) and 5.63 and 6.25 ppm (for T2, Figure S7), were diagnostic of protons belonging to a nitrogen bound to platinum(II) center, in accordance with other complexes reported in the literature [32]. The two amino protons, equivalent and easily exchangeable in the starting compound, became not equivalent and not easily exchangeable when the $\alpha$-amino group 
coordinated the Pt ion. In addition, both proton and carbon signals of the $\mathrm{CH}-\alpha$ (indicated as $\mathrm{E}$ ) in T1 and T2 were markedly downfield shifted with respect to the corresponding signal in the starting amino acid (Table 1), indicating the presence of platinum in the proximity of this group. In the ${ }^{13} \mathrm{C}$ NMR spectra of both complexes, a downfield shift from 168 to about 181 ppm of the carboxylic carbon F was observed, indicating the coordination of the carboxylic group to the metal center. Strong evidence of the presence of DMSO as a platinum ligand in both Pt complexes came from new proton and carbon signals in T1 and T2, attributable to the methyl groups linked to the Pt-bound sulfur (downfield-shifted with respect to free DMSO), in agreement with chemical shifts reported in the literature for DMSO-containing Pt complexes [5,15].

Notably, in the explored conditions, only for T1 and not for T2, the presence of two rotamers (doubling of some proton/carbon signals) was observed. Rotamers, which are generally reported for peptide nucleic acid (PNA) or some nucleoamino acid monomers [33,34], are due to a restricted rotation around the amide bond. Thus, it can be deduced that the rotation of the nucleobase around the methylene group occurred more rapidly for T2 than for T1 in the NMR time scale.

All the NMR data indicated that both complexes coordinate platinum through the $\alpha-\mathrm{NH}_{2}$ and $\alpha-\mathrm{COOH}$ groups, whereas the nucleobase, the methylenecarbonyl linker, and the amidic nitrogen were not involved in the metal center complexation. Thus, T1 and T2 can differ only for the relative position of the DMSO and chloride ligands. To confirm the exact position of these ligands in T1 and T2, nuclear Overhauser effect spectroscopy (NOESY) experiments were also performed. A diagnostic cross peak between the proton of the amino group coordinating the platinum and the DMSO-methyl groups was found in T2 NOESY spectrum but not in T1 (Table S4 and Figure S9). Finally, molecular modeling analysis of the Pt complexes, by applying the MMFF94 energy minimization method [35,36], confirmed the observed NOESY correlations (Figures S10 and S11, realized using the MOLVIEW program [35]). Taken together, the obtained data concurred to define for T1 and T2 the structures reported in Scheme 1, whereas for the initially obtained complexes, we hypothesize the structures depicted in Figure S11 (bottom).

To definitively confirm the structures of T1 and T2, as well as of their precursors, we tried to crystalize them in different ways to perform X-ray diffraction studies. Unfortunately, attempts to obtain good quality crystals were unsuccessful, and only decomposition products were observed.

\subsection{UV-Vis Analysis of $\mathbf{T} 1$ and $\mathbf{T} 2$ Platinum Complexes in Aqueous Solution}

Before analyzing the UV-vis behavior of T1 and T2 in aqueous solution, we first characterized the absorption spectral properties of the starting nucleoamino acid DAP(T)-OH. The UV spectrum of DAP(T)-OH, dissolved at $80 \mu \mathrm{M}$ conc. in PBS (phosphate-buffered saline, $137 \mathrm{mM} \mathrm{NaCl}, 2.7 \mathrm{mM}$ $\mathrm{KCl}, 10 \mathrm{mM} \mathrm{Na}_{2} \mathrm{HPO}_{4}, 1.8 \mathrm{mM} \mathrm{KH}_{2} \mathrm{PO}_{4}$ ), showed an intense band at $268 \mathrm{~nm}$, characteristic of the thymine nucleobase $\left(\varepsilon_{260}=8560 \mathrm{M}^{-1} \mathrm{~cm}^{-1}\right)$ [37]. The UV signal was monitored over time up to $96 \mathrm{~h}$. Apart from a very slight increase in the 268-nm band in the first $24 \mathrm{~h}$, no significant spectral changes were observed over a longer monitoring time, indicating good stability of DAP(T)-OH in the tested buffer solution (Figure S12).

The UV-vis spectra of T1 and T2 complexes in PBS showed, in both cases, the main band relative to the thymine chromophore almost overlapped to that of $\mathrm{DAP}(\mathrm{T})-\mathrm{OH}$, further confirming that the nucleobase does not participate to the $\mathrm{Pt}$ coordination. This band, having a high extinction molar coefficient, probably submerged possible absorption bands relative to metal/ligands charge-transfer transitions. Indeed, only a weak band at about $330 \mathrm{~nm}$, which proved the presence of the metal in the complexes, was detected (Figure 2). 


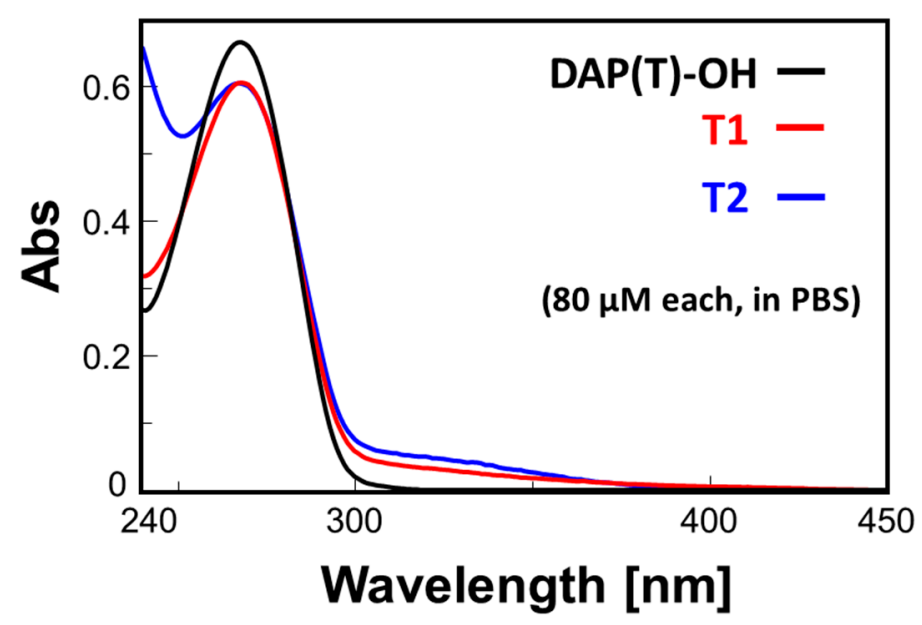

Figure 2. Overlapped ultraviolet-visible (UV-vis) spectra of the two platinum complexes (T1 and T2) and the starting ligand $\mathrm{DAP}(\mathrm{T})-\mathrm{OH}$ dissolved at $80 \mu \mathrm{M}$ concentration in phosphate-buffered saline (PBS).

The stability of the complexes was evaluated by monitoring their UV spectra in PBS over time for $48 \mathrm{~h}$. In the first hour of monitoring, an increase in both the 268 and $330 \mathrm{~nm}$ bands occurred with a concomitant $1 \mathrm{~nm}$ red-shift of the maximum of the 268-nm band (Figures S13a and S14a). Then, after $1 \mathrm{~h}$, the weak metal-to-ligand charge transfer (MLCT) band started to decrease, probably due to the exchange reactions between water and the labile ligands. The overall UV signal stabilized after $48 \mathrm{~h}$ (Figures S13b and S14b).

Overall, the variations in the UV-vis spectra of both metal complexes were barely detectable, resulting in a slight hyperchromic- and red-shift of the band at $268 \mathrm{~nm}$ and a small decrease in the $330 \mathrm{~nm}$ band (Figures S13c and S14c).

\subsection{NMR Analysis of $\mathbf{T} 1$ and $\mathbf{T} 2$ Platinum Complexes in Aqueous Solution}

Since only moderate changes were detected in the UV-vis spectra of T1 and T2 in aqueous solution during the time-course experiments, due to the strong absorption of the nucleobase with respect to the weak MLCT bands of the metal complexes, we followed their stability over time using another technique. In particular, by using ${ }^{1} \mathrm{H}-\mathrm{NMR}$ experiments, we observed that both the platinum complexes were stable for months in DMSO- $\mathrm{d}_{6}$. By adding $10 \% \mathrm{D}_{2} \mathrm{O}$ to the DMSO- $\mathrm{d}_{6}$ solution of T1 and T2, we evidenced the appearance of new signals and the intensity reduction of others, denoting that more than one species was formed from the original ones. However, with only $10 \%$ water, the complexes were still quite stable. Indeed, the new species started appearing after $8 \mathrm{~h}$, and intact T1 and T2 were still present in the solution for almost 50\% of their initial amount after $48 \mathrm{~h}$ (see Figure S15a for T2). Probably, the first exchanged ligand by water was chloride, followed (after at least $24 \mathrm{~h}$ ) by DMSO, as evidenced by the appearance of the free DMSO signal (at $2.23 \mathrm{ppm}$ ). The hydrolysis of the Pt complexes was also monitored by dissolving them directly in $\mathrm{D}_{2} \mathrm{O}$. Obviously, in this case, the process was faster, affording the complete exchange of the DMSO ligand after $48 \mathrm{~h}$, and the detachment from the metal also of the DAP(T)-OH ligand after $96 \mathrm{~h}$ (see Figure S15b for T2 complex). Even if monitoring T1 behavior was complicated by the presence of the rotamers, which rendered the spectra interpretation more difficult, by following the appearance of the free DMSO signal in both the complexes dissolved in $\mathrm{D}_{2} \mathrm{O}$, we observed a slightly faster exchange of this ligand for $\mathbf{T} 2$ than for T1 (Figure S16).

\subsection{Antiproliferative Activity of the $\mathbf{T} \mathbf{1}$ and $\mathbf{T} \mathbf{2}$ Platinum Complexes}

The antiproliferative effects of $\mathbf{T} 1$ and $\mathbf{T} 2$ complexes were evaluated on three different tumor cell lines (i.e., HeLa, human cervical adenocarcinoma; WM266, metastatic melanoma; MCF-7, breast adenocarcinoma) and one healthy cellular model (HDF, human fibroblasts). Cells were treated with 
solutions of $\mathrm{Pt}(\mathrm{II})$ complexes and DAP(T)-OH freshly diluted in growth medium at 25 and $50 \mu \mathrm{M}$ concentrations, and after $48 \mathrm{~h}$, the 3-(4,5-dimethylthiazol-2-yl)-2,5-diphenyltetrazolium bromide (MTT) assay was performed. The percentage of living cells with respect to the control (cells treated only with the vehicle) for each compound is reported in Figure 3.

a)

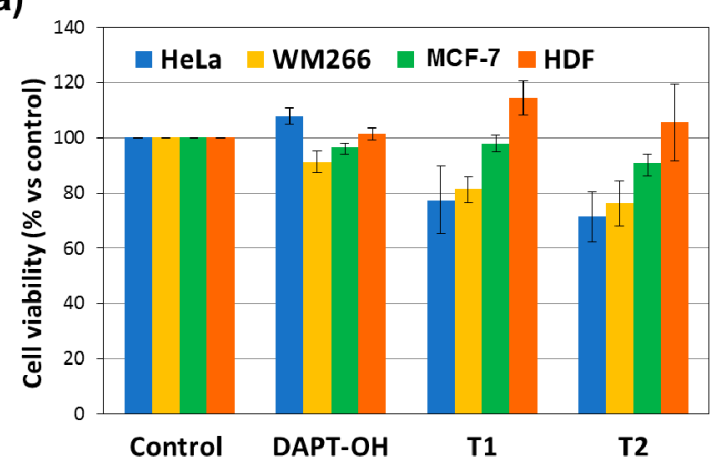

b)

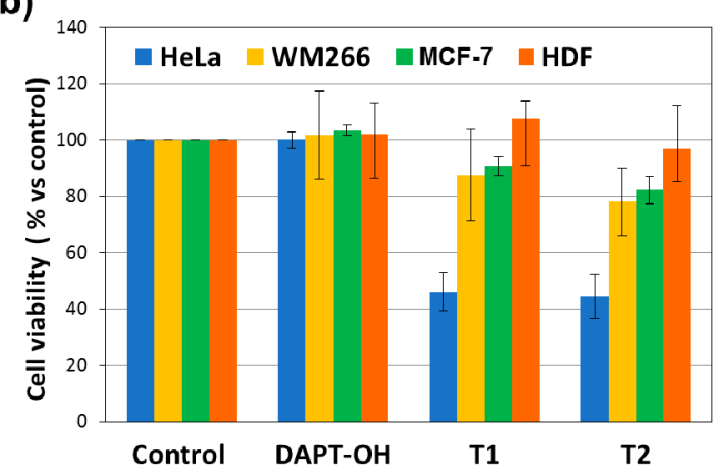

Figure 3. Cell viability assay on human cervical adenocarcinoma (HeLa), metastatic melanoma (WM266), breast adenocarcinoma (MCF-7), and human fibroblasts (HDF). Cells were incubated with T1, $\mathrm{T} 2$, or DAP(T)-OH at 25 (a) or 50 (b) $\mu \mathrm{M}$ concentration at $37{ }^{\circ} \mathrm{C}$ for $48 \mathrm{~h}$. Cell viability was measured by using the 3-(4,5-dimethylthiazol-2-yl)-2,5-diphenyltetrazolium bromide (MTT) assay. The results are presented as the percentage of living cells with respect to the control (vehicle-treated cells) and are expressed as means $\pm \mathrm{SE}$ of at least three independent experiments performed in triplicate.

The results indicated that the complexes showed a good antiproliferative activity on HeLa cells with a cell viability reduction of $23 \%$ and $29 \%$, at $25 \mu \mathrm{M}$, and $55 \%$ and $54 \%$ at $50 \mu \mathrm{M}$, respectively, for T1 and T2. The target complexes were less active on WM266 and MCF-7 cells, reducing their viability by about $20 \%$ at the highest concentration tested $(50 \mu \mathrm{M})$. In turn, the free ligand $\mathrm{DAP}(\mathrm{T})-\mathrm{OH}$ did not affect the proliferation of all the tested cells, indicating that the activity found for T1 and T2 is essentially due to the presence of platinum.

However, $\mathbf{T} 1$ and $\mathbf{T} 2$ complexes proved to be less active than cisplatin (used as positive control) on the treated tumor cells, but, remarkably, more selective with respect to the healthy ones (Figure S17). In fact, T1 and T2 did not interfere with the HDF proliferation at the tested concentrations (Figure 3).

\subsection{CD-Monitored Binding Experiments of the New Platinum Complexes with DNA Model Systems}

Subsequently, the novel Pt(II) complexes T1 and T2, as well as the nucleoamino acid DAP(T)-OH, were studied by CD spectroscopy in their interaction in solution with DNA sequences representing useful model systems [38,39]. In detail, we used a 12-mer random coil single strand (ODN1) containing a central box with two contiguous guanines (GG box), and three secondary structure-forming oligonucleotides (ODNs), i.e., two hairpin duplexes of 12 base-pairs (one with and the other without a central GG box), and a unimolecular G-quadruplex (G4) model with three G-quartets. The hairpin duplexes were formed by two 27-mer self-complementary single strands, classical models for B DNA duplexes (ds27: two tracts of the Dickerson sequence joined by a central three-thymine (TTT) loop [40,41]; and dsGG: two 12-mer tracts, one of which contained a GG box, joined by a central TTT loop), whereas the unimolecular G4 was derived from the 26-mer human telomere sequence $\left(\right.$ tel $\left._{26}\right)$, which can form in proper conditions G-quadruplex structures. The strong interest for G-quadruplexes is due to the formation of these non-canonical DNA structures in some regions of the human genome, especially in telomeres and in regulatory regions of some oncogenes [42-44].

All the CD-binding experiments were performed in a $\mathrm{K}^{+}$-rich buffered solution $(100 \mathrm{mM} \mathrm{KCl}$, $7 \mathrm{mM} \mathrm{Na} 2 \mathrm{HPO}_{4} / \mathrm{NaH}_{2} \mathrm{PO}_{4}, \mathrm{pH}=7.2$ ) to mimic the intracellular physiological conditions. The ODNs used as DNA model systems were subjected to the annealing procedure taking the sequences in the selected buffer at high temperature $\left(95^{\circ} \mathrm{C}\right)$ for $5 \mathrm{~min}$, and then leaving them to slowly cool to room 
temperature. This procedure allows structuring either the duplexes and G4 structures, as verified by the CD spectra (Figure S18). The conformation adopted by tel ${ }_{26}$ after annealing in the selected buffer was essentially a hybrid-2 type structure, as evidenced by the comparison of its CD spectrum in Figure S18d with those reported in the literature $[45,46]$.

Since the contribution to the CD signal of the starting nucleoamino acid and the Pt complexes was negligible at the concentration used for the experiments (Figure S19), we monitored the CD profiles of the ODN systems before and after incubation with the target molecules (10 equiv.) dissolved in DMSO, at different time periods $(0,2,24$, and $48 \mathrm{~h})$ after the addition. As a reference, we also monitored upon time the CD signal of the ODN solutions after the addition of pure DMSO (same volume as the one added in previous incubations with the compounds) without evidencing significant changes in the overall CD spectra.

As shown in Figure 4a,b, significant changes in the CD spectrum of ODN1 were observed when this was treated with T1 and T2, evidencing that both complexes interacted with this single strand oligonucleotide. In contrast, the starting nucleoamino acid did not produce relevant CD variations on ODN1 (Figure 4c). In detail, in the presence of T1, the CD spectrum of ODN1 showed a decrease over time of the band at $275 \mathrm{~nm}$ accompanied by a red-shift of the band maximum reaching the highest effects $48 \mathrm{~h}$ after the complex addition $\left(\triangle C_{275}=1.3 \mathrm{mdeg}, 5 \mathrm{~nm}\right.$ red-shift $)$. More marked changes in the CD band were observed when complex T2 was added to the ODN1 solution. Upon time, the CD spectrum exhibited a dramatic decrease in the CD signal at $275 \mathrm{~nm}$ (ca 70\%) accompanied by a $10 \mathrm{~nm}$ red-shift of the band maximum.

a)

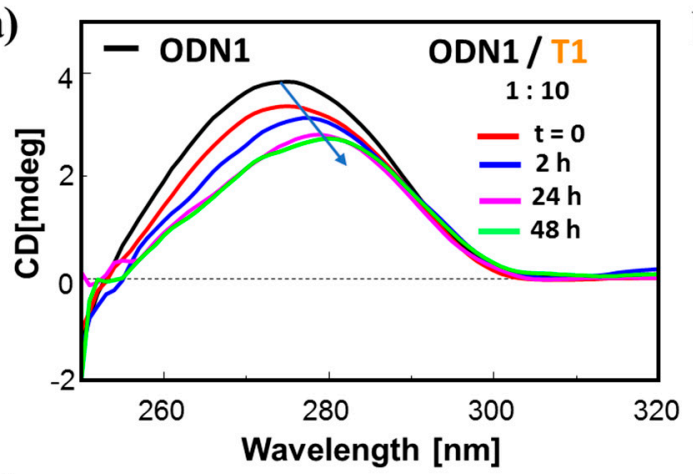

c)

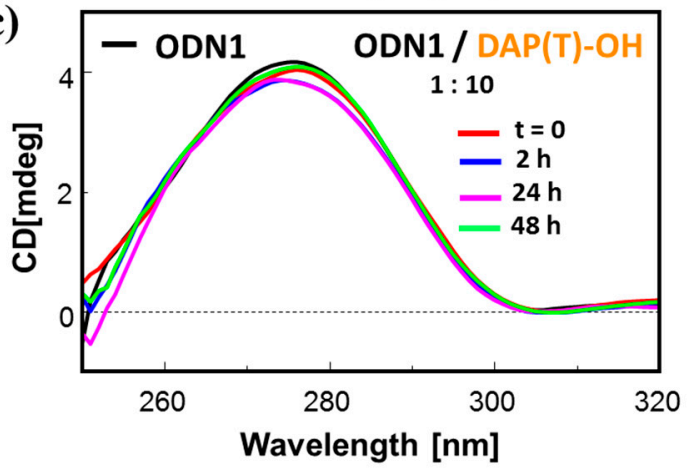

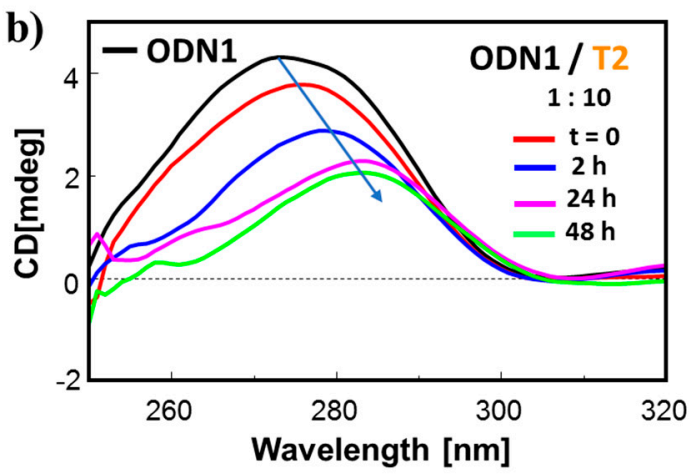

d)

\begin{tabular}{|c|c|}
\hline System & $\Delta \mathrm{CD}_{275}$ \\
\hline ODN1 / T1 & 1.306 \\
\hline ODN1 / T2 & 2.930 \\
\hline ODN1 / DAP(T)-OH & 0.080 \\
\hline
\end{tabular}

Figure 4. Overlapped circular dichroism (CD) spectra of oligonucleotide 1 (ODN1) ( $2 \mu$ M concentration), in the absence (black lines) and presence of T1 (a), T2 (b), and DAP(T)-OH (c) $(20 \mu \mathrm{M}$ each) at different times $(0,2,24,48 \mathrm{~h})$ after the addition of the target molecules. (d) Differences in the CD signal at $275 \mathrm{~nm}$ between the CD spectra of ODN1 before and after $48 \mathrm{~h}$ incubation with each added compound. The experiments were carried out in $100 \mathrm{mM} \mathrm{KCl}, 7 \mathrm{mM} \mathrm{Na} 2 \mathrm{HPO}_{4} / \mathrm{NaH}_{2} \mathrm{PO}_{4}, \mathrm{pH}=7.2$, at $20{ }^{\circ} \mathrm{C}$ (optical path $=1 \mathrm{~cm}$ ).

Similarly to ODN1, CD spectroscopy was used to evaluate the interaction of T1, T2, and DAP(T)-OH with the selected duplex DNA models. In these cases, small changes in the CD spectra of the duplexes were observed when T1 and T2 were added to the oligonucleotide 
solutions (Figure S20a,b,e,f), whereas no changes were recorded for the incubation with DAP(T)-OH (Figure S20c,g). In particular, with both the duplex systems, a reduction in the CD signal of about 1 mdeg was observed after incubation with T1 (Figure S20a,d for ds27, and Figure S20e,h for dsGG). T2 also produced a red-shift of the band maximum of the duplexes of ca. $2 \mathrm{~nm}$, along with a CD intensity decrease, which, however, was more pronounced for the duplex containing the GG box compared to ds27 (Figure S20b,d for ds27 and Figure S20f,h for dsGG).

As far as the interactions with the G4 was concerned, only slight differences between the CD spectrum of tel ${ }_{26}$ in the absence and presence of the nucleoamino acid DAP(T)-OH were observed up to $48 \mathrm{~h}$ (Figure $5 \mathrm{c}$ ). In contrast, after the addition of $\mathbf{T} 1$ or $\mathbf{T} 2$ to the G4 solution, both the main band at $290 \mathrm{~nm}$ and the shoulder at $267 \mathrm{~nm}$ significantly decreased over time, reaching, also in this case, the maximum effects after $48 \mathrm{~h}$ incubation (Figure $5 \mathrm{a}, \mathrm{b}$ ).

a)

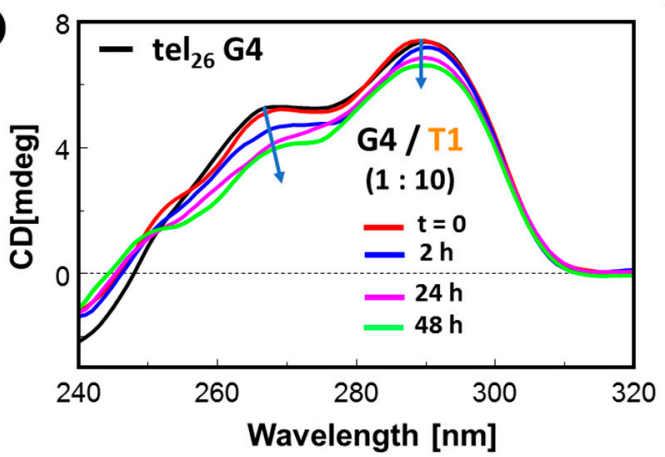

c)

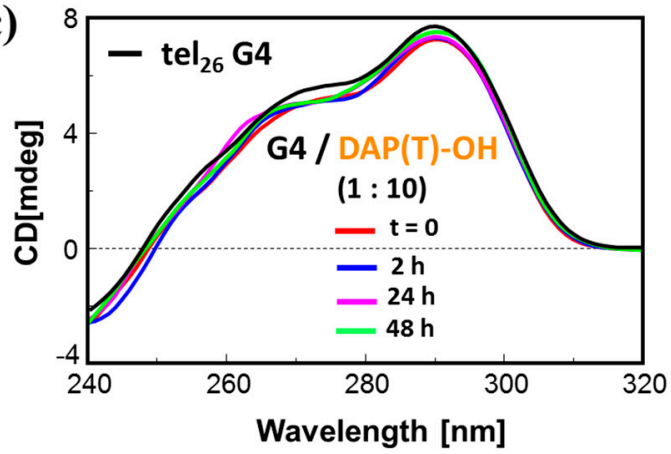

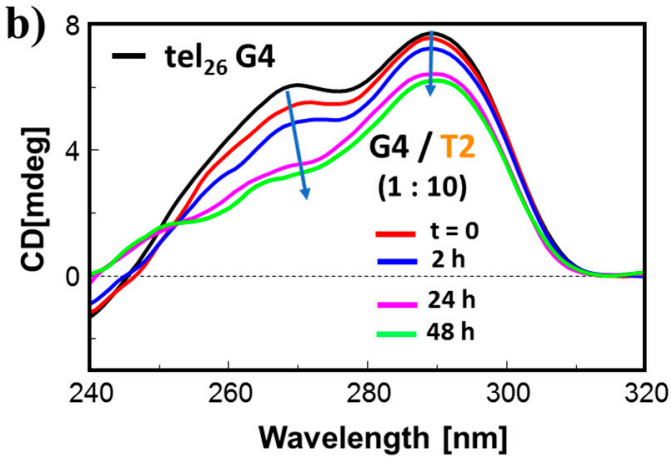

d)

\begin{tabular}{|c|c|c|}
\hline System & $\Delta \mathrm{CD}_{290}$ & $\Delta \mathrm{CD}_{267}$ \\
\hline $\mathbf{G 4} / \mathrm{T1}$ & 0.77 & 1.43 \\
\hline $\mathbf{G 4} / \mathbf{T 2}$ & 1.49 & 3.02 \\
\hline $\mathbf{G 4} /$ DAP(T)-OH & 0.10 & 0.25 \\
\hline
\end{tabular}

Figure 5. Overlapped CD spectra of the G-quadruplex (G4) tel ${ }_{26}(2 \mu \mathrm{M}$ concentration), in the absence (black lines) and presence of T1 (a), T2 (b), and DAP(T)-OH (c) $(20 \mu \mathrm{M}$ each) at different times (0, 2, $24,48 \mathrm{~h}$ ) after the addition of the target molecules. (d) Differences in the CD signal at 290 and $267 \mathrm{~nm}$ between the CD spectra of the G4, before and after $48 \mathrm{~h}$ incubation with each added compound. The experiments were carried out in $100 \mathrm{mM} \mathrm{KCl}, 7 \mathrm{mM} \mathrm{Na} 2 \mathrm{HPO}_{4} / \mathrm{NaH}_{2} \mathrm{PO}_{4}, \mathrm{pH}=7.2$, at $20{ }^{\circ} \mathrm{C}$ (optical path $=1 \mathrm{~cm}$ ).

Taken together, the CD data suggested that DNA can be a possible target of the newly obtained compounds, similar to other well-known anticancer Pt complexes $[6,7,12,21,23,47,48]$, with the DAP(T)-based Pt complexes inducing important conformational changes in G4 structures and single stranded ODNs upon binding, contrarily to the duplex structure (either containing or not the GG box).

To compare the ability of the complexes to bind the different DNA systems with that of cisplatin, the same CD experiments performed with $\mathbf{T} 1$ and $\mathbf{T} 2$ were also carried out with CDDP under identical experimental conditions. In agreement with our previous work [47], CDDP proved to significantly interact with the random-coil single strand containing a GG box (ODN1, Figure S21a) and the GG-containing duplex (dsGG, Figure S21c), whereas it was not able to perturb or disrupt the compact G4 structure of tel ${ }_{26}$ (Figure S21d) nor the duplex not-containing the GG box (Figure S21b). Furthermore, while CDDP evidenced a clear selectivity towards duplex structures containing a GG box 
(dsGG vs. ds27, Figure S21b,c), T1 and T2 did not efficiently interact with duplex structures, either containing or not a GG-box element (Figure S20b,c).

Finally, since the UV bands of T1, T2, and DAP(T)-OH significantly overlapped with those of the selected ODN systems, contrarily to CD analysis, UV data were not useful to interpret the binding behavior of these complexes towards different DNA structures.

\subsection{PAGE-Monitored Binding Experiments of the New Platinum Complexes with DNA Model Systems}

The structured DNA model systems that had evidenced, from the CD studies, the higher conformational variations upon binding with the Pt complexes, were selected for native polyacrylamide gel electrophoresis (PAGE) experiments to obtain qualitative data on DNA platination and compare the behavior of $\mathbf{T} 1$ and $\mathbf{T} 2$ with that of CDDP. In particular, the G4 tel ${ }_{26}$ and the duplex containing the GG box (dsGG) were incubated separately for $48 \mathrm{~h}$ with 10 equiv. of $\mathbf{T} 1, \mathbf{T} 2$, and CDDP at room temperature. Inspection of the gel, reported in Figure 6a, evidenced that DNA platination on the GG-duplex occurred efficiently by CDDP, as expected, and to a less extent by $\mathbf{T} 1$ and T2 (with T2 > T1), whereas the G4 tel $_{26}$ was platinated more by $\mathbf{T} 1$ and $\mathbf{T} 2$ (T2 $>$ T1) than by CDDP (Figure 6b). Thus, PAGE data were in perfect agreement with the CD results (Figure S20e,f, Figure 5a,b, and Figure S21c,d).

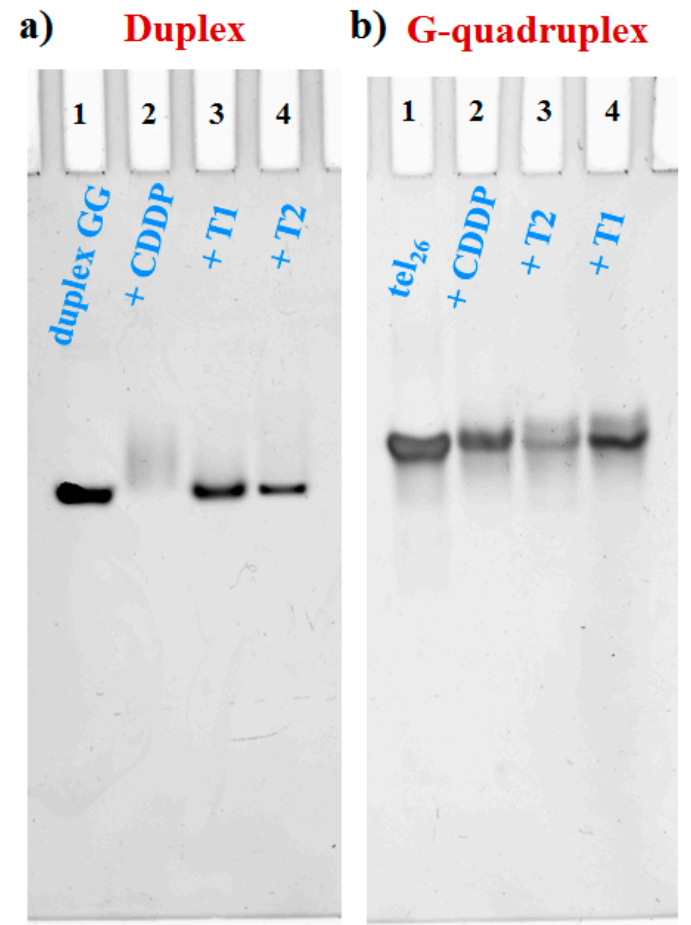

Figure 6. Representative $25 \%$ polyacrylamide gel electrophoresis (PAGE) under native conditions relative to the GG-duplex (a) and the G-quadruplex (b) DNA systems ( $2 \mu$ M concentration), alone (lanes 1 ) or incubated for $48 \mathrm{~h}$ with 10 equiv. of CDDP, T1 and T2 in $100 \mathrm{mM} \mathrm{KCl}, 7 \mathrm{mM} \mathrm{Na} 2 \mathrm{HPO}_{4} / \mathrm{NaH}_{2} \mathrm{PO}_{4}$, $\mathrm{pH}=7.2$. Gel was run at $80 \mathrm{~V}$, at r.t. for $3.3 \mathrm{~h}$ in TBE $1 \times$ buffer.

To exclude the contribution of DMSO in the appearance of additional, smeared DNA bands after ligand incubation, the oligonucleotides were also treated in the same conditions with equal amounts of this solvent without the ligands. In these experiments, no difference with the reference DNA bands was evidenced, demonstrating that the observed effects were not due to the solvent (Figure S22). 


\section{Materials and Methods}

\subsection{Reagents, Instruments, and General Methods}

All the reagents and solvents were of the highest commercially available quality and were used as received. The coupling reactions were performed under an argon atmosphere, and all the reagents were previously co-evaporated with anhydrous $\mathrm{CH}_{3} \mathrm{CN}$. Thin layer chromatography (TLC) analyses were carried out on silica gel plates from Macherey-Nagel (60, F254). Reaction products on TLC plates were visualized by $254 \mathrm{~nm}$ UV-light. DNA sequences were provided by Biomers.net $\mathrm{GmbH}$ (Ulm, Germany).

NMR spectra were recorded on Bruker Avance III HD $400 \mathrm{MHz}$ and Varian Inova $500 \mathrm{MHz}$ NMR spectrometers, as specified. All the chemical shifts $(\delta)$ in ${ }^{1} \mathrm{H}$ - and ${ }^{13} \mathrm{C}-\mathrm{NMR}$ spectra are expressed in ppm with respect to the residual solvent $\left(\mathrm{CHD}_{2} \mathrm{SOCD}_{3}, \mathrm{DMSO}-\mathrm{d}_{5}, \delta=2.50 \mathrm{ppm}\right.$, quintet) or tetramethylsilane (TMS) signals. All the coupling constants $(J)$ are quoted in Hertz (Hz). The following abbreviations were used to explain the multiplicities: $\mathrm{s}=$ singlet; $\mathrm{d}=$ doublet; $\mathrm{t}=$ triplet; $\mathrm{q}=$ quartet; quin $=$ quintet $; \mathrm{m}=$ multiplet; $\mathrm{b}=$ broad .

MALDI-TOF mass spectrometric analyses were performed on a TOF/TOF 5800 System in a positive mode, using 2,5-dihydroxybenzoic acid (DHB) or $\alpha$-cyano-4-hydroxycinnamic acid (CHCA) as the matrices. For the deposition on the MALDI plate, the droplet spotting method was used. The sample $\left(1 \mathrm{mg} / \mathrm{mL}\right.$ in $\mathrm{CH}_{3} \mathrm{CN} / \mathrm{CH}_{3} \mathrm{OH}$ or $\left.\mathrm{CH}_{3} \mathrm{CN} / \mathrm{H}_{2} \mathrm{O}, 7: 3, v / v\right)$ was first deposited on the plate $(0.5 \mu \mathrm{L})$ followed by matrix deposition $(10 \mathrm{mg} / \mathrm{mL}$ in the same solvent mixture of the sample) and properly mixed before drying the components.

LC-ESI-MS analyses were performed on an Agilent 6230B TOF LC/MS instrument, equipped with a 1260 Infinity HPLC analytical system with binary pump coupled with a 6230 time of flight mass spectrometer as a detector and an Electrospray source; an Agilent ZORBAX C18 column $(1.8 \mu \mathrm{m}$, $50 \times 4.6 \mathrm{~mm}$ ) for reverse-phase liquid chromatography were used. Stock solutions of the samples were prepared at $2 \mathrm{mg} / \mathrm{mL}$ concentration in $\mathrm{HPLC}$ grade $\mathrm{CH}_{3} \mathrm{CN} / \mathrm{H}_{2} \mathrm{O}$. The injections were carried out at a final concentration of $4 \mathrm{ng} / \mu \mathrm{L}$ in $\mathrm{CH}_{3} \mathrm{CN} / \mathrm{H}_{2} \mathrm{O}$, using a flow rate of $0.4 \mathrm{~mL} / \mathrm{min}$. Column elution was performed using $\mathrm{H}_{2} \mathrm{O}$ (A) (with or without $0.05 \%$ TFA, as specified) and $\mathrm{CH}_{3} \mathrm{CN}$ (B) as eluents. An isocratic elution of $B$ in $A$ for 3 min was followed by a gradient elution increasing $B$ over $10 \mathrm{~min}$. The ESI/TOF-MS was operated in positive ion mode (100-1500 $\mathrm{m} / \mathrm{z}$ values).

The semipreparative purifications were carried out on a Hewlett Packard/Agilent 1100 series HPLC system, equipped with a UV detector, using a Phenomenex Luna C18 $100 \AA$ ( $5 \mu \mathrm{m}, 4.6 \times 150 \mathrm{~mm})$ column. Gradient elution was carried out at $25^{\circ} \mathrm{C}$ (monitoring at $254 \mathrm{~nm}$ ) by using a gradient that started with buffer A (0.05\% TFA in water) and applying buffer B (0.05\% TFA in acetonitrile) with a flow rate of $1 \mathrm{~mL} \mathrm{~min}^{-1}$.

Samples were lyophilized in an FD4 Freeze Dryer (Heto Lab Equipment) for $16 \mathrm{~h}$.

UV-vis measurements were performed on a JASCO V-550 UV-vis spectrophotometer equipped with Peltier Thermostat JASCO ETC-505T.

CD spectra were recorded with a Jasco J-715 spectropolarimeter equipped with a Peltier-type temperature control system (model PTC-348WI).

Energy-minimized 3D structure models (random low energy conformers) were obtained by using the 3D rendering engine JSmol and applying the MMFF94 energy minimization method [36] coded in MolView v2.4 (http://molview.org) software [35].

Acrylamide/bis-acrylamide (19:1) 40\% solution, GelGreen Nucleic Acid Stain, and Tris-BorateEthylenediaminetetraacetic Acid (EDTA) (TBE) 10X were purchased from VWR. Ammonium persulfate (APS) and tetramethylethylenediamine (TEMED) were purchased from Sigma-Aldrich. 


\subsection{Synthesis of the $D A P(T)-O H$ Nucleoaminoacid}

3.2.1. Fmoc-DAP(T)-OH, (S)-2-[(9H-fluoren-9-yl)methoxycarbonylamino]-3-\{2-[5-methyl-2,4-dioxo3,4-dihydropyrimidin-1(2H)-yl]acetamido\} propanoic acid (2)

Fmoc-protected nucleoamino acid 3 (Scheme 1) was obtained as previously reported, with minor modifications [30]. Briefly, commercially available Fmoc/Boc-protected L-2,3-diaminopropanoic acid 1 (Fmoc-L-Dap(Boc)-OH: $51 \mathrm{mg}$, $0.120 \mathrm{mmol}$; Scheme 1) was treated with a 1:1 TFA/ $\mathrm{CH}_{2} \mathrm{Cl}_{2}$ solution $(2 \mathrm{~mL})$, and the mixture was left under stirring at $45^{\circ} \mathrm{C}$ for $1.5 \mathrm{~h}$. Then, the solvent was removed in vacuo, and the crude was treated with cold diethyl ether. A white precipitate, recovered by filtration, was repeatedly washed with cold diethyl ether and finally dried in vacuo. This product corresponded to desired Fmoc-DAP-OH (2,38 mg, $0.118 \mathrm{mmol}$, almost quantitative yield), as confirmed by TLC and NMR analysis [30]. Compound 2 was then dissolved in anhydrous DMF (1 mL), treated with DIEA (1 equiv., $0.118 \mathrm{mmol}, 21 \mu \mathrm{L}$ ) and reacted with commercially available thymine acetic acid (2.2 equiv., $0.260 \mathrm{mmol}, 48 \mathrm{mg}$ ), previously activated with HATU ( 2.0 equiv., $0.230 \mathrm{mmol}, 89 \mathrm{mg}$ ) and DIEA ( 4.0 equiv., $0.470 \mathrm{mmol}, 82 \mu \mathrm{L}$ ) in DMF $(1 \mathrm{~mL})$ for $3 \mathrm{~min}$. After $3 \mathrm{~h}$ at room temperature, under magnetic stirring and argon atmosphere, the solvent was removed in vacuo. The crude material was treated with a $0.1 \%$ TFA aq. solution and filtered off to remove the aqueous solution from the white precipitate. This solid was resuspended in a mixture of $\mathrm{H}_{2} \mathrm{O} / \mathrm{CH}_{3} \mathrm{CN}(7: 3, v / v)$ containing $0.1 \%$ TFA and purified by semipreparative HPLC according to a gradient elution starting from $\mathrm{H}_{2} \mathrm{O} / \mathrm{CH}_{3} \mathrm{CN}$ (both containing $0.1 \%$ TFA) $=78: 22$, and increasing the amount of $\mathrm{CH}_{3} \mathrm{CN}$ to $70 \%$ in $20 \mathrm{~min}$. The desired product (3), whose identity was confirmed by TLC, MS, and NMR analysis [30], was obtained as a pure compound in good yield ( $46 \mathrm{mg}, 0.094 \mathrm{mmol}, 80 \%$ yield).

3.2.2. DAP(T)-OH, (S)-2-amino-3-\{2-[5-methyl-2,4-dioxo-3,4-dihydropyrimidin-1(2H)-yl]acetamido\} propanoic acid (4)

Isolated product $3(46 \mathrm{mg}, 0.094 \mathrm{mmol})$ was dissolved in $2 \mathrm{~mL}$ of a $10 \%$ piperidine solution in DMF: $\mathrm{CH}_{3} \mathrm{OH}(9: 1, v / v)$. After 10 min stirring at room temperature, TLC analysis indicated the complete removal of the Fmoc group. Then the solvent was removed under vacuum and the crude was resuspended with cold diethyl ether obtaining a white precipitate. This species was recovered after centrifugation, by discarding the supernatant, washing with cold diethyl ether $(3 \times 5 \mathrm{~mL})$ and drying. Lyophilization from $\mathrm{H}_{2} \mathrm{O}$ (containing $0.1 \%$ TFA) allowed obtaining the desired compound 4 in almost quantitative yield ( $25 \mathrm{mg}, 0.092 \mathrm{mmol})$ : white powder. $R f=0.1\left(\mathrm{CH}_{2} \mathrm{Cl}_{2} / \mathrm{CH}_{3} \mathrm{OH}, 8: 2, v / v\right)$. Mass calculated for $4\left(\mathrm{C}_{10} \mathrm{H}_{14} \mathrm{~N}_{4} \mathrm{O}_{5}=\mathrm{M}\right)$ : 270.10 u.m.a.; MALDI-TOF-MS (positive ions, Figure S1, up) m/z found: $271.00[\mathrm{M}+\mathrm{H}]^{+}, 293.13[\mathrm{M}+\mathrm{Na}]^{+}, 309.10[\mathrm{M}+\mathrm{K}]^{+}$; ESI-MS (positive ions, Figure S1, bottom) $m / z$ found: $271.14[\mathrm{M}+\mathrm{H}]^{+}, 292.98[\mathrm{M}+\mathrm{Na}]^{+}, 308.95[\mathrm{M}+\mathrm{K}]^{+} .{ }^{1} \mathrm{H} \mathrm{NMR}\left(400 \mathrm{MHz}, \mathrm{D}_{2} \mathrm{O}\right.$; Figure S2, up): $\delta 7.44$ (s, 1H, CH-6), 4.55 (bs, 2H, $\left.\mathrm{CH}_{2}-\mathrm{A}\right), 3.93(\mathrm{~m}, 1 \mathrm{H}, \mathrm{CH} \alpha-\mathrm{E}), 3.87\left(\mathrm{bd}, J=15.0 \mathrm{~Hz}, 1 \mathrm{H}, \mathrm{CH}_{2}-\mathrm{D}_{1}\right.$ ), 3.68 (bdd, $\left.1 \mathrm{H}, J=15.0,5.9 \mathrm{CH}_{2}-\mathrm{D}_{2}\right), 1.90\left(\mathrm{~s}, 3 \mathrm{H}, \mathrm{CH}_{3}-5\right) .{ }^{13} \mathrm{C} \mathrm{NMR}\left(100 \mathrm{MHz}, \mathrm{D}_{2} \mathrm{O}\right.$; Figure S2, bottom): $\delta 172.56$ (COOH-F); 171.29 (C-B); 167.70 (C-4); 153.13 (C-2); 143.83 (CH-6); 111.85 (C-5); $55.69\left(\mathrm{CH}_{2}-\mathrm{A}\right)$; 51.18 (CH-E); $40.66\left(\mathrm{CH}_{2}-\mathrm{D}\right) ; 11.98\left(\mathrm{CH}_{3}-5\right) .{ }^{1} \mathrm{H}$ NMR (500 MHz, DMSO-d $\mathrm{d}_{6}$; Figure S3, up): $\delta 8.35$ (bt, 1H, NH-C); 7.41 (s, 1H, CH-6); 4.31 (AB system, 2H, CH $-\mathrm{A}$ ); 3.53 (bdt, $J=13.6,4.5 \mathrm{~Hz}, 1 \mathrm{H}, \mathrm{CH}_{2}-\mathrm{D}_{1}$ ); $3.33\left(\mathrm{~m}, 1 \mathrm{H}, \mathrm{CH}_{2}-\mathrm{D}_{1}\right) ; 3.27(\mathrm{~m}, 1 \mathrm{H}, \mathrm{CH} \alpha-\mathrm{E}) ; 1.75\left(\mathrm{~s}, 3 \mathrm{H}, \mathrm{CH}_{3}-5\right) .{ }^{13} \mathrm{C}$ NMR $(125 \mathrm{MHz}$, DMSO-d 6 ; Figure S3, bottom): $\delta 168.82$ (COOH-F), 167.77 (C-B), 164.36 (C-4), 151.05 (C-2), 142.31 (C-6), 108.01 (C-5), 54.04 (CH-E), $49.16\left(\mathrm{CH}_{2}-\mathrm{A}\right), 39.62\left(\mathrm{CH}_{2}-\mathrm{D}\right), 11.87\left(\mathrm{CH}_{3}-5\right)$. UV-vis spectrum of 4 (Figure 2): band maximum at $268 \mathrm{~nm}\left(\varepsilon_{260}=8700 \mathrm{M}^{-1} \mathrm{~cm}^{-1}\right)$.

\subsection{Platination Reaction of $\mathrm{DAP}(\mathrm{T})-\mathrm{OH}$}

The nucleoamino acid derivative $\mathrm{DAP}(\mathrm{T})-\mathrm{OH}(4,25 \mathrm{mg}, 0.092 \mathrm{mmol})$ was suspended in $\mathrm{CH}_{3} \mathrm{OH}$ (1.35 mL). In parallel, $\mathrm{K}_{2} \mathrm{PtCl}_{4}$ (1 equiv., $10.58 \mathrm{mg}, 0.092 \mathrm{mmol}$ ) was dissolved in the minimum amount of $\mathrm{H}_{2} \mathrm{O}(150 \mu \mathrm{L})$. In $1 \mathrm{~h}$, the amino acid solution was slowly added to the aqueous solution of $\mathrm{K}_{2} \mathrm{PtCl}_{4}$ (final solvents ratio: $\mathrm{CH}_{3} \mathrm{OH} / \mathrm{H}_{2} \mathrm{O}, 9: 1, v / v$ ). The reaction mixture was kept under stirring in the 
dark and at room temperature for $6 \mathrm{~h}$ until the formation of an almost clear yellow solution from the initial dark orange one, with the concomitant disappearance of the $\mathrm{DAP}(\mathrm{T})-\mathrm{OH}$ white suspension. Subsequently, the solvent was removed under vacuum at $30^{\circ} \mathrm{C}$, and the reaction crude was dried for $1 \mathrm{~h}$ at the oil pump to remove traces of $\mathrm{H}_{2} \mathrm{O}$. Then, the crude mixture was sequentially resuspended after sonication in various solvents (dichloromethane, chloroform, and acetone) and centrifuged, affording, in all cases, a dark-yellow precipitate and a colorless supernatant. This solution, analyzed by TLC, did not show UV-vis bands and was consequently discarded. In contrast, treatment of the precipitate with $\mathrm{CH}_{3} \mathrm{OH}$ gave a pale-yellow solution and a dark-yellow precipitate. Thus, a series of centrifugations and washings of the precipitate with $\mathrm{CH}_{3} \mathrm{OH}$ (until the supernatant was completely colorless) was performed, and the combined yellow methanol solutions (ca. $6 \times 5 \mathrm{~mL}$ ) were taken to dryness. Then, the dark-yellow solid was resuspended by sonication with $\mathrm{H}_{2} \mathrm{O}$ obtaining a yellow supernatant and a white precipitate. After centrifugations and washings of the precipitate with $\mathrm{H}_{2} \mathrm{O}$ (until the supernatant was completely colorless), the aqueous solutions (ca. $3 \times 5 \mathrm{~mL}$ ) were combined, and immediately frozen and lyophilized to remove water from the complex. The white precipitate was then discarded, and the two obtained yellow components (yellow powders) were separately analyzed. LC-ESI-MS analysis of the two Pt complexes was performed as follows: the complexes were dissolved in $\mathrm{H}_{2} \mathrm{O} / \mathrm{CH}_{3} \mathrm{CN}(9: 1, v / v)$, injected on a C18 column, and eluted in gradient mode ( 3 min isocratic elution with $5 \% \mathrm{CH}_{3} \mathrm{CN}$ in $\mathrm{H}_{2} \mathrm{O}$, then gradient to $50 \% \mathrm{CH}_{3} \mathrm{CN}$ in $10 \mathrm{~min}$; $t_{\mathrm{R}}=0.94$ and $0.89 \mathrm{~min}$, for methanol- and water-recovered $\mathrm{Pt}$ complexes, respectively; see Figure S4a).

Since the most common NMR organic solvents $\left(\mathrm{CDCl}_{3}, \mathrm{CD}_{3} \mathrm{OD}, \mathrm{CD}_{3} \mathrm{COCD}_{3}\right)$ did not solubilize the recovered $\mathrm{Pt}$ complexes at a proper concentration for a complete NMR characterization, we used DMSO for their solubilization. The newly obtained DAP(T)-based complexes were named $\mathbf{T} 1$ and T2 (originated from the DMSO-exchange reaction of the Pt complex recovered in $\mathrm{CH}_{3} \mathrm{OH}$ and $\mathrm{H}_{2} \mathrm{O}$, respectively). The purity of the obtained complexes was checked by LC-ESI-MS, which evidenced the presence of a single peak for each compound (Figure S5a). For the LC-ESI-MS characterization, T1 and T2 were dissolved in $\mathrm{H}_{2} \mathrm{O} / \mathrm{CH}_{3} \mathrm{CN}(9: 1, v / v)$, injected on a $\mathrm{C} 18$ column, and eluted as follows: 3 min isocratic elution with $10 \% \mathrm{CH}_{3} \mathrm{CN}$ in $\mathrm{H}_{2} \mathrm{O}$, then gradient to $95 \% \mathrm{CH}_{3} \mathrm{CN}$ in $10 \min \left(t_{\mathrm{R}}=0.94\right.$ and $0.84 \mathrm{~min}$, for $\mathbf{T} 1$ and $\mathbf{T} 2$, respectively).

\subsubsection{T1 Characterization}

Mass calculated for $\mathbf{T 1}\left(\mathrm{C}_{12} \mathrm{H}_{20} \mathrm{ClN}_{4} \mathrm{O}_{6} \mathrm{Pt}=\mathrm{M}\right)$ : 578.23 u.m.a.; LC-ESI-MS (positive ions; Figure S5a, left) $\mathrm{m} / \mathrm{z}$ found: $579.10[\mathrm{M}+\mathrm{H}]^{+}, 601.08[\mathrm{M}+\mathrm{Na}]^{+}, 617.06[\mathrm{M}+\mathrm{K}]^{+}$(chromatographic peak at $0.94 \mathrm{~min}$ ). ${ }^{1} \mathrm{H}$ NMR (400 MHz, DMSO-d 6 ; Figure S6): $\delta$ 11.29/11.28 (s, two rotamers, NH-3/3'), 8.58/8.48 (bt, two rotamers, $\left.J=5.7 / 5.6, \mathrm{NH}-\mathrm{C} / \mathrm{C}^{\prime}\right), 7.44 / 7.43$ (s, two rotamers, $\left.\mathrm{H}-6 / 6^{\prime}\right), 6.29\left(\mathrm{bs}, \mathrm{NH}_{2}-\mathrm{G}_{1}\right), 5.68\left(\mathrm{bs}, \mathrm{NH}_{2}-\mathrm{G}_{2}\right)$, 4.35 (AB system, $\mathrm{CH}_{2}-\mathrm{A}$ ), $3.90\left(\mathrm{bm}, \mathrm{CH}_{2}-\mathrm{E}\right), 3.64\left(\mathrm{bdt}, J=14.53,5.06 \mathrm{~Hz}, \mathrm{CH}_{2}-\mathrm{D}_{1}\right.$ ), 3.59-3.26 (overlapped signals; in decreasing ppm order: $\left.\mathrm{CH}_{2}-\mathrm{D}_{1}{ }^{\prime}, \mathrm{CH}_{2}-\mathrm{E}^{\prime}, \mathrm{CH}_{2}-\mathrm{D}_{2} / \mathrm{D}_{2}{ }^{\prime}\right), 3.16$ (bs, $\mathrm{CH}_{3}-\mathrm{DMSO}-\mathrm{Pt}$ ), 1.75 (s, $\left.\mathrm{CH}_{3}-5\right) .{ }^{13} \mathrm{C}$ NMR (125 MHz, DMSO-d ${ }_{6}$; Figure S6): $\delta 181.33$ (C-F), 168.86/168.31 (C-B/B'), 164.44/164.42 (C-4/4') 151.05 (C-2), 142.24 (C-6), 108.10/107.98 (C-5/5'), 56.78 (CH-E), 52.40 (CH-E'), $49.22\left(\mathrm{CH}_{2}-\mathrm{A}\right)$, $49.02\left(\mathrm{CH}_{3}\right.$-DMSO-Pt), $41.66\left(\mathrm{CH}_{2}-\mathrm{D}^{\prime}\right), 38.58\left(\mathrm{CH}_{2}-\mathrm{D}\right), 11.93 / 11.91\left(\mathrm{CH}_{3}-5 / 5^{\prime}\right)$.

\subsubsection{T2 Characterization}

Mass calculated for $\mathbf{T} 2\left(\mathrm{C}_{12} \mathrm{H}_{20} \mathrm{ClN}_{4} \mathrm{O}_{6} \mathrm{Pt}=\mathrm{M}\right)$ : 578.23 u.m.a.; LC-ESI-MS (positive ions; Figure S5a, right) $\mathrm{m} / z$ found: $578.91[\mathrm{M}+\mathrm{H}]^{+}, 601.15[\mathrm{M}+\mathrm{Na}]^{+}, 617.24[\mathrm{M}+\mathrm{K}]^{+}$(chromatographic peak at $0.84 \mathrm{~min}$ ). ${ }^{1} \mathrm{H}$ NMR (400 MHz, DMSO-d 6 ; Figure S7): $\delta 11.30$ (s, 1H, NH-3), 8.43 (bs, $\left.1 \mathrm{H}, \mathrm{NH}-\mathrm{C}\right), 7.43$ (s, 1H, H-6); 6.25 (bs, $\left.1 \mathrm{H}, \mathrm{NH}_{2}-\mathrm{G}_{1}\right), 5.63$ (bs, $\left.1 \mathrm{H}, \mathrm{NH}_{2}-\mathrm{G}_{2}\right), 4.34$ (s, 2H, $\left.\mathrm{CH}_{2}-\mathrm{A}\right), 3.65-3.27$ (overlapped signals; in decreasing ppm order: $\mathrm{CH}_{2}-\mathrm{D}_{1}, \mathrm{CH}_{2}-\mathrm{E}, \mathrm{CH}_{2}-\mathrm{D}_{2}$ ), 3.16 (bs, $\left.\mathrm{CH}_{3}-\mathrm{DMSO}-\mathrm{Pt}\right), 1.75$ (s, 3H, $\left.\mathrm{CH}_{3}-5\right) .{ }^{13} \mathrm{C}$ NMR (100 MHz, DMSO-d ${ }_{6}$; Figure S8): $\delta 181.38$ (C-F), 168.44 (C-B), 164.47 (C-4), 151.07 (C-2), 142.23 (C-6), 108.16 (C-5), 56.90 (CH-E), $49.27\left(\mathrm{CH}_{2}-\mathrm{A}\right), 48.61\left(\mathrm{CH}_{3}-\mathrm{DMSO}-\mathrm{Pt}\right), 41.69\left(\mathrm{CH}_{2}-\mathrm{D}\right)$, $11.94\left(\mathrm{CH}_{3}-5\right)$. 
Several attempts to obtain also MALDI-TOF spectra of the two complexes were performed using CHCA and DHB as matrixes and various laser powers, obtaining, in all cases, many adducts with the matrix and degradation products.

Based on their chemical structures (as deduced by NMR and mass data), the synthesis yields of $\mathrm{T} 1$ and $\mathbf{T} 2$ from the complexation reaction of $\mathrm{DAP}(\mathrm{T})-\mathrm{OH}$ with $\mathrm{K}_{2} \mathrm{PtCl}_{4}$ followed by DMSO-exchange, were 35 and $23 \%$, respectively.

Attempts to obtain crystals of the initial complexes, as well as of T1 and T2, suitable for X-ray crystallography, failed, giving only degradation products (white crystals).

\subsection{MTT Assay}

\subsubsection{Cell Cultures}

Human adenocarcinoma (HeLa), human metastatic melanoma (WM266), breast adenocarcinoma (MCF-7) cell lines were purchased from ATCC (U.S.). Normal human dermal fibroblasts (HDF) were kindly provided by Dr. A. Tito Arterra, Biosciences (Napoli, Italy). HeLa, MCF-7, and HDF were grown in Dulbecco's Modified Eagle's Medium (DMEM) supplemented with $10 \%$ fetal bovine serum (FBS), $1 \%$ glutamine, $100 \mathrm{U} / \mathrm{mL}$ penicillin, and $100 \mu \mathrm{g} / \mathrm{mL}$ streptomycin (Euroclone, Milano, Italy). WM266 were grown in RPMI, as previously described [38,39,49]. Cells were maintained in humidified air containing $5 \% \mathrm{CO}_{2}$ at $37^{\circ} \mathrm{C}$.

\subsubsection{Cell Proliferation Experiments}

Cells were plated at a density of 1200 cells/well for HeLa, 2000 for WM266, MCF-7, and HDF in 96-well microplates (Corning) and incubated at $37^{\circ} \mathrm{C}$. After $24 \mathrm{~h}$, cells were treated for $48 \mathrm{~h}$ with the compounds previously solubilized. In detail, the Pt complexes and DAP(T)-OH were dissolved in DMSO at a $10 \mathrm{mM}$ concentration, while cisplatin was solubilized in an aqueous solution of DMSO $(10 \%) / \mathrm{NaCl}(0.9 \%)$, at a $2 \mathrm{mM}$ concentration [50], then diluted with growth medium until the final solution contained no more than $0.5 \%$ DMSO, well-tolerated by in vitro cell cultures. Cell proliferation was determined by using the 3-(4,5-dimethylthiazol-2-yl)-2,5-diphenyltetrazolium bromide assay (MTT, Sigma Aldrich, Milano, Italy) after $48 \mathrm{~h}$ incubation [51]. Plates were then analyzed using a microplate reader (Enspire, Perkin Elmer, Waltham, MA, USA) at $570 \mathrm{~nm}$. The results are reported as the percentage of living cells with respect to the control (vehicle-treated cells) and are expressed as means \pm SE of at least three independent experiments performed in triplicate.

\subsection{UV-Vis Experiments}

The UV spectra were recorded using a scanning speed of $100 \mathrm{~nm} / \mathrm{min}$ and a $2.0 \mathrm{~nm}$ bandwidth with the appropriate baseline subtraction. A quartz cuvette with a path length of $1 \mathrm{~cm}$ was used (3.5 $\mathrm{mL}$ internal volume). The UV-vis spectra of the compounds were recorded in PBS (137 $\mathrm{mM} \mathrm{NaCl}$, $2.7 \mathrm{mM} \mathrm{KCl}, 10 \mathrm{mM} \mathrm{Na}_{2} \mathrm{HPO}_{4}, 1.8 \mathrm{mM} \mathrm{KH}_{2} \mathrm{PO}_{4}$ ) over time in the range of 220 to $450 \mathrm{~nm}$ to study their stability. The solutions analyzed were $80 \mu \mathrm{M}$ in PBS and were obtained after dilution from the original stock solution (7 $\mathrm{mM}$ in DMSO).

\subsection{Experiments}

The CD spectra were recorded at $20^{\circ} \mathrm{C}$ in a quartz cuvette with a path-length of $1 \mathrm{~cm}$ using the following parameters: spectral window $240-320 \mathrm{~nm}$, response $1 \mathrm{~s}$, scanning speed $100 \mathrm{~nm} / \mathrm{min}$, bandwidth $2.0 \mathrm{~nm}$. All the spectra were averaged over 3 scans and corrected by subtraction of the background scan with buffer. For all the experiments, oligonucleotides were dissolved at $2 \mu \mathrm{M}$ concentration, stock solutions of ligands $[\mathrm{T1}, \mathrm{T} 2$, and $\mathrm{DAP}(\mathrm{T})-\mathrm{OH}]$ were prepared at $7 \mathrm{mM}$ conc. in DMSO, whereas stock CDDP solution was obtained at a $7 \mathrm{mM}$ concentration in an aqueous solution of DMSO (10\%)/ $\mathrm{NaCl}(0.9 \%)$ [50]. A buffer solution of $7 \mathrm{mM} \mathrm{Na} 2 \mathrm{HPO}_{4} / \mathrm{NaH}_{2} \mathrm{PO}_{4}, 100 \mathrm{mM}$ 
$\mathrm{KCl}(\mathrm{pH}$ 7.2) was used for the studies on the interaction between the DNA model systems and the platinum-based complexes.

The tested DNA sequences were the following (GG boxes are underlined and in italic):

ODN1 = CCTCT $\underline{G G T C T C C ~(s i n g l e ~ s t r a n d ~ m o d e l) ; ~}$

ds27 = CGCGAATTCGCG TTT CGCGAATTCGCG (duplex model not-containing a GG box);

dsGG = CATGTGGTTCTG TTT CAGAACCACATG (duplex model containing one GG box); tel $_{26}=$ TTA $\underline{G G G T T A} \underline{G G G T T A G G G T T A G G G T T}$ (G-quadruplex model).

\subsection{PAGE Experiments}

Annealed oligonucleotides samples, dissolved at $2 \mu \mathrm{M}$ concentration in $7 \mathrm{mM} \mathrm{Na}_{2} \mathrm{HPO}_{4} / \mathrm{NaH}_{2} \mathrm{PO}_{4}$, $100 \mathrm{mM} \mathrm{KCl}$ (pH 7.2) were incubated with 10 equiv. of each platinum complex. After $48 \mathrm{~h}$ incubation at room temperature (r.t.), the samples, including the reference DNA, were loaded on $25 \%$ polyacrylamide gels in TBE $1 \times$ as running buffer. All the mixtures were supplemented with $5 \%$ glycerol just before loading and then run, under native conditions, at $80 \mathrm{~V}$ at r.t. for $3.3 \mathrm{~h}$. Gels were stained with a GelGreen solution (supplemented with $0.1 \mathrm{M} \mathrm{NaCl}$ ) for $30 \mathrm{~min}$ and finally visualized with a UV transilluminator (BioRad ChemiDoc XRS, Milano, Italy). Each experiment was performed in duplicate.

\section{Conclusions}

In this work, the nucleoamino acid $\mathrm{DAP}(\mathrm{T})-\mathrm{OH}$, derived by the coupling of $\mathrm{L}$-2,3-diaminopropanoic acid with a thymine acetic acid, was synthesized and characterized via mass spectrometry and NMR spectroscopy and used for the reaction with a platinum(II) salt to obtain novel $\mathrm{Pt}$ (II) complexes. Two new platinum-based complexes, named $\mathbf{T} 1$ and $\mathbf{T} 2$, were obtained and characterized by various techniques. These compounds include in their structures one nucleoamino acid unit [DAP(T)-OH], a platinum(II) ion, a chloride ion, and a DMSO molecule. The identity of the new metal complexes was ascertained by NMR spectroscopy $\left({ }^{1} \mathrm{H}\right.$ and ${ }^{13} \mathrm{C}, \mathrm{COSY}, \mathrm{HSQC}, \mathrm{HMBC}$, and NOESY experiments) and mass spectrometry (LC-ESI-MS) techniques.

The cytotoxicity of T1 and T2, as well as of DAP(T)-OH used as a reference, was tested, in preliminary assays, on a panel of human cancer (HeLa, WM266, MCF-7) and normal (HDF) cells using the MTT assay. CDDP was also tested as a positive control. Both the Pt complexes showed good antiproliferative activity on HeLa cells. Indeed, T1 and T2 at $50 \mu \mathrm{M}$ concentration reduced HeLa cell viability more than $50 \%$ after $48 \mathrm{~h}$ incubation, whereas, at the same tested concentration, they were less active on WM266 and MCF-7, suggesting a selectivity of action towards the specific tumor cells that is an important feature in cancer therapy. It is worth noting that, although $\mathbf{T} 1$ and $\mathbf{T} 2$ complexes resulted less effective in blocking cell proliferation than cisplatin, they were more selective towards cancer cells than healthy ones, as demonstrated by comparing the activity on HeLa cells with that observed on HDF ones, on which the complexes were essentially inactive even at the highest concentration tested. Interestingly, the free ligand $\mathrm{DAP}(\mathrm{T})-\mathrm{OH}$ did not affect all the tested cells indicating that the observed bioactivity is essentially driven by the presence of the platinum center.

We also hypothesized that the nucleobase could contribute to the bioactivity of the Pt complexes by both protecting the $\mathrm{Pt}$ center from premature deactivation and increasing the cellular uptake of the complexes, plausibly thanks to specific nucleobase transporters, thus giving a synergistic effect together with the presence of the metal. Furthermore, generally, single nucleobases do not show relevant biological activity (nor significantly interact with DNA). In addition, as previously reported [21], the Pt complex with DAP-OH as ligand did not evidence significant antiproliferative activity in the same experimental conditions, showing a 50\% inhibition of HeLa cells proliferation only at $220 \mu \mathrm{M}$ concentration, whereas $\mathbf{T} \mathbf{1}$ and $\mathbf{T} 2$ seemed to be about 4-times more active on the same cancer cells.

Once the antiproliferative effects of the platinum-based complexes were assessed, to explore if their activity could be correlated with their DNA-binding ability, T1 and T2, as well as DAP(T)-OH and cisplatin, used as reference compounds, were studied using CD spectroscopy. Their interaction in solution was investigated with four DNA model systems, i.e., a random coil single strand, two B 
form-duplexes, one with and the other without a GG box, and a G-quadruplex structure. From CD binding experiments, it emerged that DNA can be a possible target of these brand new compounds, similar to other reported bioactive Pt complexes (as well as transition metal complexes, such as ruthenium complexes) $[6,7,12,15,21,23,47,48,52,53]$. In particular, we observed significant changes only in the CD spectrum of the single strand and G4 when T1 and T2 were added to each DNA system, evidencing that both the complexes interacted with these oligonucleotides. A more marked interaction seemed to occur in the case of $\mathbf{T} 2$ with respect to T1. On the contrary, the interaction of the starting nucleoamino acid with all the tested DNA systems was almost null, in line with the absence of specific antiproliferative effects observed in cell assays. Thus, CD data were in agreement with the observed biological activity for all the compounds. Furthermore, comparing the DNA-binding behavior of the new Pt complexes with that of cisplatin, it emerged that, while CDDP efficiently interacted with duplex structures containing a $G G$ box not being able to perturb or disrupt the compact structure of the G4, T1 and T2 resulted good G4-binders as revealed by both CD- and PAGE-monitored binding experiments.

The moderate cytotoxicity combined with the selectivity of the $\mathrm{Pt}(\mathrm{II})$ complexes obtained and described in the present work, can be of pharmaceutical interest in multiple drug therapy. In addition, the synthesis and characterization of DAP-based nucleoamino acids also containing the other nucleobases, i.e., $\mathrm{DAP}(\mathrm{C})-\mathrm{OH}, \mathrm{DAP}(\mathrm{A})-\mathrm{OH}$, and $\mathrm{DAP}(\mathrm{G})-\mathrm{OH}$, are ongoing in our laboratories to use these nucleamino acid scaffolds as building blocks for the preparation of novel $\mathrm{Pt}$ complexes endowed with increased activity and selectivity, identifying the most promising analogs of the series.

Supplementary Materials: The following are available online at http://www.mdpi.com/1424-8247/13/10/284/s1.

Author Contributions: Conceptualization, D.M. (Domenica Musumeci), D.M. (Daniela Montesarchio), G.N.R.; Methodology, D.M. (Domenica Musumeci), D.M. (Daniela Montesarchio); Software, G.N.R.; Formal analysis, D.M. (Domenica Musumeci), D.M. (Daniela Montesarchio); Investigation, C.R., D.C., A.C., C.P., S.D.G., D.M. (Domenica Musumeci); Resources, D.M. (Daniela Montesarchio), D.M. (Domenica Musumeci), G.N.R., D.C., S.D.G.; Data curation, D.M. (Domenica Musumeci), C.R., D.C.; Writing—original draft preparation, D.M. (Domenica Musumeci); Writing-review and editing, C.R., C.P., D.M. (Daniela Montesarchio), D.M. (Domenica Musumeci); All authors have read and agreed to the published version of the manuscript.

Funding: We are grateful to the financial support received from the H2020-MSCA-RISE-2019 under grant agreement No 872331 (acronym: NoBiasFluors).

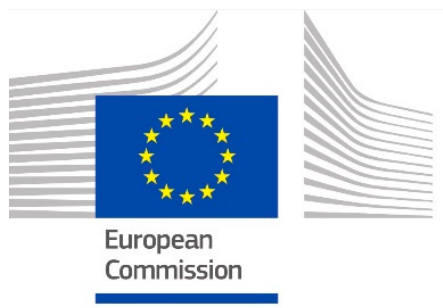

Conflicts of Interest: The authors declare no conflict of interest.

\section{Abbreviations}

A (adenine), APS (ammonium persulfate), B (nucleobase), Boc (tert-butoxycarbonyl), C (cytosine), CD (circular dichroism), CDDP (cis-diaminedichloro-platinum), CHCA ( $\alpha$-cyano-4-hydroxycinnamic acid), COSY (correlation spectroscopy), DAP (2,3-diaminopropanoic acid), DHB (2,5-dihydroxybenzoic acid), DIEA (N,N-diisopropylethylamine), DMEM (Dulbecco's Modified Eagle's Medium), DMF (N,N-dimethylformamide), DMSO (dimethyl sulfoxide), EDTA (Ethylenediaminetetraacetic Acid), ESI (electrospray ionization), FBS (fetal serum bovine), Fmoc (9-fluorenylmethoxycarbonyl), G (Guanine), G4 (G-quadruplex), HATU (1-[bis(dimethylamino)methylene]-1H-1,2,3-triazolo[4,5-b]pyridinium 3-oxid hexafluorophosphate), HDF (human dermal fibroblast), HeLa (cervical cancer cells), HMBC (heteronuclear multiple-bond correlation), HPLC (high-performance liquid-chromatography), HSQC (heteronuclear single quantum correlation), LC (liquid chromatography), MALDI (matrix-assisted laser desorption ionization), MCF-7 (human breast adenocarcinoma cell line), MS (mass spectrometry), MTT (3-(4,5-dimethylthiazol-2-yl)-2,5-diphenyltetrazolium bromide), NMR (nuclear magnetic resonance), NOESY (nuclear overhauser effect spectroscopy), ODN (oligodeoxyribonucleotide), PAGE (polyacrylamide gel electrophoresis), PBS (phosphate-buffered saline), PNA (peptide nucleic acid), ppm (parts per million), $R_{\mathrm{f}}$ (retention factor), r.t. (room temperature), TBE (Tris-Borate-EDTA), TEMED (tetramethylethylenediamine), TFA (trifluoroacetic acid), TOC (Thin layer chromatography), TOF (time of flight), $t_{\mathrm{R}}$ (retention time), WM (Wistar melanoma cell lines). 


\section{References}

1. Dasari, S.; Bernard Tchounwou, P. Cisplatin in cancer therapy: Molecular mechanisms of action. Eur. J. Pharmacol. 2014, 740, 364-378. [CrossRef] [PubMed]

2. Makovec, T. Cisplatin and beyond: Molecular mechanisms of action and drug resistance development in cancer chemotherapy. Radiol. Oncol. 2019, 53, 148-158. [CrossRef] [PubMed]

3. Wexselblatt, E.; Yavin, E.; Gibson, D. Cellular interactions of platinum drugs. Inorg. Chim. Acta 2012, 393, 75-83. [CrossRef]

4. Gasior-Głogowska, M.; Malek, K.; Zajac, G.; Baranska, M. A new insight into the interaction of cisplatin with DNA: ROA spectroscopic studies on the therapeutic effect of the drug. Analyst 2016, 141, 291-296. [CrossRef]

5. Mügge, C.; Liu, R.; Görls, H.; Gabbiani, C.; Michelucci, E.; Rüdiger, N.; Clement, J.H.; Messori, L.; Weigand, W. Novel platinum(II) compounds with O,S bidentate ligands: Synthesis, characterization, antiproliferative properties and biomolecular interactions. Dalton Trans. 2014, 43, 3072-3086. [CrossRef]

6. Hardie, M.; Kava, H.; Murray, V. Cisplatin analogues with an increased interaction with DNA: Prospects for therapy. Curr. Pharm. Des. 2016, 22, 6645-6664. [CrossRef]

7. Cucciolito, M.E.; D’Amora, A.; De Feo, G.; Ferraro, G.; Giorgio, A.; Petruk, G.; Monti, D.M.; Merlino, A.; Ruffo, F. Five-coordinate Platinum(II) compounds containing sugar ligands: Synthesis, characterization, cytotoxic activity, and interaction with biological macromolecules. Inorg. Chem. 2018, 57, 3133-3143. [CrossRef]

8. Iakovidis, A.; Hadjiliadis, N. Complex compounds of platinum (II) and (IV) with amino acids, peptides and their derivatives. Coord. Chem. Rev. 1994, 135-136, 17-63. [CrossRef]

9. Liu, R.; Li, H.; Gao, X.; Mi, Q.; Zhao, H.; Gao, Q. Mannose-conjugated platinum complexes reveals effective tumor targeting mediated by glucose transporter 1. Biochem. Biophys. Res. Commun. 2017, 487, 34-40. [CrossRef]

10. Sengupta, P.; Basu, S.; Soni, S.; Pandey, A.; Roy, B.; Oh, M.S.; Chin, K.T.; Paraskar, A.S.; Sarangi, S.; Connor, Y.; et al. Cholesterol-tethered platinum II-based supramolecular nanoparticle increases antitumor efficacy and reduces nephrotoxicity. PNAS 2012, 109, 11294-11299. [CrossRef]

11. Ratzon, E.; Najajreh, Y.; Salem, R.; Khamaisie, H.; Ruthardt, M.; Mahajna, J. Platinum (IV)-fatty acid conjugates overcome inherently and acquired Cisplatin resistant cancer cell lines: An in-vitro study. BMC Cancer 2016, 16, 1-11. [CrossRef] [PubMed]

12. Riccardi, C.; Capasso, D.; Rozza, G.M.; Platella, C.; Montesarchio, D.; Di Gaetano, S.; Marzo, T.; Pratesi, A.; Messori, L.; Roviello, G.N.; et al. Synthesis, DNA binding studies, and antiproliferative activity of novel $\mathrm{Pt}(\mathrm{II})$-complexes with an L-alanyl-based ligand. J. Inorg. Biochem. 2020, 203, 110868. [CrossRef] [PubMed]

13. D'Errico, S.; Oliviero, G.; Piccialli, V.; Amato, J.; Borbone, N.; D'Atri, V.; D'Alessio, F.; Di Noto, R.; Ruffo, F.; Salvatore, F.; et al. Solid-phase synthesis and pharmacological evaluation of novel nucleoside-tethered dinuclear platinum(II) complexes. Bioorg. Med. Chem. 2011, 21, 5835-5838. [CrossRef] [PubMed]

14. D’Errico, S.; Oliviero, G.; Borbone, N.; Piccialli, V.; Pinto, B.; De Falco, F.; Maiuri, M.C.; Carnuccio, R.; Costantino, V.; Nici, F.; et al. Synthesis and pharmacological evaluation of modified adenosines joined to mono-functional platinum moieties. Molecules 2014, 19, 9339-9353. [CrossRef]

15. Chen, J.; Li, K.; Swavey, S.; Church, K.M. Synthesis, characterization and DNA binding activity of $\mathrm{PtCl}_{2}$ [DMSO][N $\mathrm{N}_{4}$ [N-3(4-pyridylmethyl)thymidine]]. Inorg. Chim. Acta 2016, 444, 76-80. [CrossRef]

16. Cincinelli, R.; Musso, L.; Dallavalle, S.; Artali, R.; Tinelli, S.; Colangelo, D.; Zunino, F.; De Cesare, M.; Beretta, G.L.; Zaffaroni, N. Design, modeling, synthesis and biological activity evaluation of camptothecin-linked platinum anticancer agents. Eur. J. Med. Chem. 2013, 63, 387-400. [CrossRef]

17. Pastor-Anglada, M.; Pérez-Torras, S. Nucleoside transporter proteins as biomarkers of drug responsiveness and drug targets. Front. Pharmacol. 2015, 6, 1-14. [CrossRef]

18. Inoue, K. Molecular basis of nucleobase transport systems in mammals. Biol. Pharm. Bull. 2017, 40, 1130-1138. [CrossRef]

19. Jin, V.X.; Ranford, J.D. Complexes of platinum(II) or palladium(II) with 1,10-phenanthroline and amino acids. Inorg. Chim. Acta 2000, 304, 38-44. [CrossRef]

20. Krylova, L.F.; Kovtunova, L.M.; Romanenko, G.V. Pt(II) and Pd(II) complexes with $\beta$-alanine. Bioinorg. Chem. Appl. 2008, 2008, 983725. [CrossRef] 
21. Moradell, S.; Lorenzo, J.; Rovira, A.; Robillard, M.S.; Avilés, F.X.; Moreno, V.; De Llorens, R.; Martinez, M.A.; Reedijk, J.; Llobet, A. Platinum complexes of diaminocarboxylic acids and their ethyl ester derivatives: The effect of the chelate ring size on antitumor activity and interactions with GMP and DNA. J. Inorg. Biochem. 2003, 96, 493-502. [CrossRef]

22. Altman, J.; Wilchek, M.; Warshawsky, A. Platinum(II) complexes with 2,4-diaminobutyric acid, ornithine, lysine and 4,5-diaminovaleric acid. Inorg. Chim. Acta 1985, 107, 165-168. [CrossRef]

23. Ziegler, C.J.; Sandman, K.E.; Liang, C.H.; Lippard, S.J. Toxicity of platinum(II) amino acid (N,O) complexes parallels their binding to DNA as measured in a new solid phase assay involving a fluorescent HMG1 protein construct readout. J. Biol. Inorg. Chem. 1999, 4, 402-411. [CrossRef] [PubMed]

24. Moradell, S.; Lorenzo, J.; Rovira, A.; Van Zutphen, S.; Avilés, F.X.; Moreno, V.; De Llorens, R.; Martinez, M.A.; Reedijk, J.; Llobet, A. Water-soluble platinum(II) complexes of diamine chelating ligands bearing amino-acid type substituents: The effect of the linked amino acid and the diamine chelate ring size on antitumor activity, and interactions with 5'-GMP and DNA. J. Inorg. Biochem. 2004, 98, 1933-1946. [CrossRef] [PubMed]

25. Roviello, G.N.; Musumeci, D.; Moccia, M.; Castiglione, M.; Sapio, R.; Valente, M.; Bucci, E.M.; Perretta, G.; Pedone, C. dabPNA: Design, synthesis, and DNA binding studies. Nucleosides Nucleotides Nucleic Acids 2007, 26, 1307-1310. [CrossRef]

26. Roviello, G.N.; Musumeci, D.; Pedone, C.; Bucci, E.M. Synthesis, characterization and hybridization studies of an alternate nucleo- $\varepsilon / \gamma$-peptide: Complexes formation with natural nucleic acids. Amino Acids 2010, 38, 103-111. [CrossRef]

27. Roviello, G.N.; Musumeci, D.; Bucci, E.M.; Pedone, C. Synthesis of a diaminopropanoic acid-based nucleoamino acid and assembly of cationic nucleopeptides for biomedical applications. Amino Acids 2012, 43, 2537-2543. [CrossRef]

28. Roviello, G.N.; Musumeci, D.; D'Alessandro, C.; Pedone, C. Synthesis of a thymine-functionalized nucleoamino acid for the solid phase assembly of cationic nucleopeptides. Amino Acids 2013, 45, 779-784. [CrossRef]

29. Roviello, G.N.; Musumeci, D. Synthetic approaches to nucleopeptides containing all four nucleobases, and nucleic acid-binding studies on a mixed-sequence nucleo-oligolysine. RSC Adv. 2016, 6, 63578-63585. [CrossRef]

30. Musumeci, D.; Roviello, V.; Roviello, G.N. DNA- and RNA-binding ability of oligoDapt, a nucleobase-decorated peptide, for biomedical applications. Int. J. Nanomed. 2018, 13, 2613-2629. [CrossRef]

31. Musumeci, D.; Mokhir, A.; Roviello, G.N. Synthesis and nucleic acid binding evaluation of a thyminyl L-diaminobutanoic acid-based nucleopeptide. Bioorg. Chem. 2020, 100, 103862. [CrossRef] [PubMed]

32. D’Errico, S.; Borbone, N.; Piccialli, V.; Di Gennaro, E.; Zotti, A.; Budillon, A.; Vitagliano, C.; Piccialli, I.; Oliviero, G. Synthesis and evaluation of the antitumor properties of a small collection of PtII complexes with 7-deazaadenosine as scaffold. Eur. J. Org. Chem. 2017, 2017, 4935-4947. [CrossRef]

33. Musumeci, D.; Roviello, G.N.; Valente, M.; Sapio, R.; Pedone, C.; Bucci, E.M. New synthesis of PNA-3'DNA linker monomers, useful building blocks to obtain PNA/DNA chimeras. Biopolym. Pept. Sci. Sect. 2004, 76, 535-542. [CrossRef] [PubMed]

34. Avitabile, C.; Moggio, L.; Malgieri, G.; Capasso, D.; Di Gaetano, S.; Saviano, M.; Pedone, C.; Romanelli, A. $\gamma$ sulphate PNA (PNA S): Highly selective DNA binding molecule showing promising antigene activity. PLOS ONE 2012, 7, e35774. [CrossRef] [PubMed]

35. Smith, T.J. MOLView: A program for analyzing and displaying atomic structures on the Macintosh personal computer. J. Mol. Graph. 1995, 13, 122-125. [CrossRef]

36. Halgren, T.A. Merck molecular force field. I. Basis, form, scope, parameterization, and performance of MMFF94. J. Comput. Chem. 1996, 17, 490-519. [CrossRef]

37. Cavaluzzi, M.J.; Borer, P.N. Revised UV extinction coefficients for nucleoside-5'-monophosphates and unpaired DNA and RNA. Nucleic Acids Res. 2004, 32, e13. [CrossRef]

38. Musumeci, D.; Roviello, G.N.; Rigione, G.; Capasso, D.; Di Gaetano, S.; Riccardi, C.; Roviello, V.; Montesarchio, D. Benzodifuran derivatives as potential antiproliferative agents: Possible correlation between their bioactivity and aggregation properties. ChemPlusChem 2017, 82, 251-260. [CrossRef] 
39. Vicidomini, C.; Cioffi, F.; Broersen, K.; Roviello, V.; Riccardi, C.; Montesarchio, D.; Capasso, D.; Di Gaetano, S.; Roviello, G.N. Benzodifurans for biomedical applications: BZ4, a selective anti-proliferative and anti-amyloid lead compound. Future Med. Chem. 2019, 11, 285-302. [CrossRef]

40. Platella, C.; Musumeci, D.; Arciello, A.; Doria, F.; Freccero, M.; Randazzo, A.; Amato, J.; Pagano, B.; Montesarchio, D. Controlled pore glass-based oligonucleotide affinity support: Towards high throughput screening methods for the identification of conformation-selective G-quadruplex ligands. Anal. Chim. Acta 2018, 1030, 133-141. [CrossRef]

41. Platella, C.; Pirota, V.; Musumeci, D.; Rizzi, F.; Iachettini, S.; Zizza, P.; Biroccio, A.; Freccero, M.; Montesarchio, D.; Doria, F. Trifunctionalized naphthalene diimides and dimeric analogues as G-quadruplex-targeting anticancer agents selected by affinity chromatography. Int. J. Mol. Sci. 2020, 21, 1964. [CrossRef]

42. Lipps, H.J.; Rhodes, D. G-quadruplex structures: In vivo evidence and function. Trends Cell Biol. 2009, 19, 414-422. [CrossRef] [PubMed]

43. Balasubramanian, S.; Hurley, L.H.; Neidle, S. Targeting G-quadruplexes in gene promoters: A novel anticancer strategy? Nat. Rev. Drug Discov. 2011, 10, 261-275. [CrossRef] [PubMed]

44. Marzano, M.; Falanga, A.P.; Marasco, D.; Borbone, N.; D’Errico, S.; Piccialli, G.; Roviello, G.N.; Oliviero, G. Evaluation of an analogue of the marine $\varepsilon$-PLL peptide as a ligand of G-quadruplex DNA structures. Mar. Drugs 2020, 18, 49. [CrossRef] [PubMed]

45. Petraccone, L.; Spink, C.; Trent, J.O.; Garbett, N.C.; Mekmaysy, C.S.; Giancola, C.; Chaires, J.B. Structure and stability of higher-order human telomeric quadruplexes. J. Am. Chem. Soc. 2011, 133, 20951-20961. [CrossRef]

46. Petraccone, L.; Pagano, B.; Giancola, C. Studying the effect of crowding and dehydration on DNA G-quadruplexes. Methods 2012, 57, 76-83. [CrossRef]

47. Musumeci, D.; Platella, C.; Riccardi, C.; Merlino, A.; Marzo, T.; Massai, L.; Messori, L.; Montesarchio, D. A first-in-class and a fished out anticancer platinum compound: Cis- $\left[\mathrm{PtCl}_{2}\left(\mathrm{NH}_{3}\right)_{2}\right]$ and cis- $\left[\mathrm{PtI}_{2}(\mathrm{NH} 3)_{2}\right]$ compared for their reactivity towards DNA model systems. Dalton Trans. 2016, 45, 8587-8600. [CrossRef]

48. Mügge, C.; Musumeci, D.; Michelucci, E.; Porru, F.; Marzo, T.; Massai, L.; Messori, L.; Weigand, W.; Montesarchio, D. Elucidating the reactivity of $\mathrm{Pt}(\mathrm{II})$ complexes with $(\mathrm{O}, \mathrm{S})$ bidentate ligands towards DNA model systems. J. Inorg. Biochem. 2016, 160, 198-209. [CrossRef]

49. Farina, B.; De Paola, I.; Russo, L.; Capasso, D.; Liguoro, A.; Del Gatto, A.; Saviano, M.; Pedone, P.V.; Di Gaetano, S.; Malgieri, G.; et al. A combined NMR and computational approach to determine the RGDechi-hCit- $\alpha v \beta 3$ integrin recognition mode in isolated cell membranes. Chemistry 2016, 22, 681-693. [CrossRef]

50. D’Errico, S.; Falanga, A.P.; Capasso, D.; Di Gaetano, S.; Marzano, M.; Terracciano, M.; Roviello, G.N.; Piccialli, G.; Oliviero, G.; Borbone, N. Probing the DNA reactivity and the anticancer properties of a novel tubercidin-Pt (II) complex. Pharmaceutics 2020, 12, 627. [CrossRef]

51. Di Gaetano, S.; Bedini, E.; Landolfi, A.; Pedone, E.; Pirone, L.; Saviano, M.; Traboni, S.; Capasso, D.; Iadonisi, A. Synthesis of diglycosylated (di)sulfides and comparative evaluation of their antiproliferative effect against tumor cell lines: A focus on the nature of sugar-recognizing mediators involved. Carbohydr. Res. 2019, 482, 107740. [CrossRef] [PubMed]

52. Musumeci, D.; Rozza, L.; Merlino, A.; Paduano, L.; Marzo, T.; Massai, L.; Messori, L.; Montesarchio, D. Interaction of anticancer $\mathrm{Ru}(\mathrm{III})$ complexes with single stranded and duplex DNA model systems. Dalton Trans. 2015, 44, 13914-13925. [CrossRef] [PubMed]

53. Riccardi, C.; Musumeci, D.; Trifuoggi, M.; Irace, C.; Paduano, L.; Montesarchio, D. Anticancer ruthenium (III) complexes and $\mathrm{Ru}(\mathrm{III})$ containing nanoformulations: An update on the mechanism of action and biological activity. Pharmaceuticals 2019, 12, 146. [CrossRef] [PubMed]

(C) 2020 by the authors. Licensee MDPI, Basel, Switzerland. This article is an open access article distributed under the terms and conditions of the Creative Commons Attribution (CC BY) license (http://creativecommons.org/licenses/by/4.0/). 